U.S. Department of the Interior

U.S. Geological Survey

\title{
Cruise Report: \\ GLORIA Survey of the Hawaiian Island Chain, \\ F2-90-HW
}

by

Shawn V. Dadisman', Michael S. Marlow ${ }^{1}$, Robin G. Rothwell ${ }^{2}$ and Malcolm Harris ${ }^{2}$

Open-File Report 92-206

'U.S. Geological Survey, Menlo Park, CA 94025

21OSDL, Wormley, Godalming, Surrey, United Kingdom GU85UB

This report is preliminary and has not been reviewed for conformity with U.S. Geological Survey editorial standards or with the North American Stratigraphic Code. Any use of trade, product or firm names is for descriptive purposes only and does not imply endorsement by the U.S. Goverment. 


\begin{abstract}
Cruise F2-90-HW was the eleventh of a fourteen cruise expedition to map the Hawaiian EEZ using the long-range side-scan sonar, GLORIA. The area surveyed imaged the Hawaiian Ridge south and west of Necker Island. In addition to GLORIA imagery, the study also collected seismic-reflection profiles, $3.5 \mathrm{kHz}$ high-resolution profiles, $10 \mathrm{kHz}$ bathymetric profiles, magnetic and gravity data, and upper water column temperature profiles.

The preliminary results show the horst and graben structure of the Cretaceous seafloor spreading fabric west of $180^{\circ}$ longitude and their associated magnetic anomaly pattern. Over 20 submarine rift zones are identified and show that rift zones play a significant role in the formation of the Hawaiian Ridge. Lava flows, of moderate size, are visible only in the central portion of the survey area.

The mass wasting processes along the western ridge appear to change from a dominance of debris avalanches seen on the younger islands to the east to less catastrophic slumps and debris slides. Only 2 debris avalanches can be identified in the GLORIA imagery for the western ridge and are the 4th and 5th largest mapped in the Hawaiian EEZ. The largest Hawaiian slump yet mapped is imaged off Gardner Pinnacles and shows a basin $9 \mathrm{~km}$ wide and $55 \mathrm{~km}$ long formed by the back-rotation of the slump block and a toe scarp that can be traced continuously for $90 \mathrm{~km}$. Five progressive slumps have been identified and are viewed as a major mode of failure along the western Hawaiian Ridge.

Submerged terraces are imaged off Maro Reef, Pioneer Bank and La Perouse Pinnacles and are similar in appearance to submerged reefs imaged and sampled off Maui. Finally, bottom currents are seen to be actively migrating east towards the base of the Hawaiian Ridge as evidenced by the presence of a $11,000 \mathrm{~km}^{2}$ bedform field imaged in the western portion of the survey area.
\end{abstract}




\section{INTRODUCTION}

Cruise F2-90-HW was the eleventh cruise conducted as part of a programmed survey of the Hawaiian Island Exclusive Economic Zone (EEZ). The multi-year co-operative program EEZ-SCAN of the United States Geological Survey (USGS) and Institute of Oceanographic Sciences (IOS), United Kingdom, is using GLORIA, a long-range side-scanning sonar, to image the territorial waters of the United States. The objectives of the program are to provide the first comprehensive survey of the Hawaiian EEZ as well as produce three reconnaissance-scale atlases of the sea-floor surface around the Hawaiian Island chain .

Cruise F2-90-HW is the third survey of the southern Hawaiian EEZ west of Necker Island (fig. 1). Two previous cruises, F13-89-HW (Pickthorn et al., 1991), and F1-90-HW (Kayen et al., 1990) surveyed the mid to outer limits of the 200-mile southern EEZ west of Necker Island. 43 tracklines were run during F2-90-HW to survey the southern territorial EEZ (fig. 1). The first two tracklines were run between Nihoa and Necker Islands to fill gaps left by previous cruises. This suite of three cruises lie adjacent and west of the area surveyed by F10-88-HW (McGregor et al., 1991). The remaining northern territorial waters of the Hawaiian EEZ were surveyed in 1991.

Operations on-board the R.V. Farnella were directed towards the collection of a variety of geophysical and acoustic data. These included: GLORIA long-range, dual channel side-scan sonar images; two-channel seismic-reflection profiles using an air-gun sound source, $3.5 \mathrm{kHz}$ high-resolution profiles, $10 \mathrm{kHz}$ bathymetric echo profiles, magnetic and gravity field records, and upper water column temperature profiles using expendable bathythermo-profilers. 
U.S. Geological Survey

\begin{tabular}{|c|c|}
\hline $\begin{array}{l}\text { Shawn V. Dadisman } \\
\text { Greg Hajic } \\
\text { Larry Kooker } \\
\text { Michael S. Marlow } \\
\text { LedaBeth Pickthorn } \\
\text { Barbara Seekins }\end{array}$ & $\begin{array}{l}\text { Chief Scientist - Geologist } \\
\text { Watchstander } \\
\text { Electronic Engineer } \\
\text { Chief Scientist - Geophysicist } \\
\text { Navigator - Watchstander } \\
\text { DAFE - Watchstander }\end{array}$ \\
\hline \multicolumn{2}{|c|}{ Institute of Oceanographic Sciences, U.K. } \\
\hline $\begin{array}{l}\text { Malcolm Harris } \\
\text { Robert E. Kirk } \\
\text { Robin G. Rothwell } \\
\text { Stephen Whittler }\end{array}$ & $\begin{array}{l}\text { GLORIA Engineer } \\
\text { GLORIA Engineer } \\
\text { Chief Scientist - Geologist } \\
\text { Mechanical Engineer }\end{array}$ \\
\hline \multicolumn{2}{|c|}{ Research Vessel Services, Barry, U.K. } \\
\hline Adrian M. Fem & Navigator \\
\hline \multicolumn{2}{|c|}{ SHIP'S CREW } \\
\hline & Marr \\
\hline $\begin{array}{l}\text { John D. Cannan } \\
\text { Albert Fuller } \\
\text { David Shaw } \\
\text { Michael Baldwin } \\
\text { David Rogerson } \\
\text { Athur Green } \\
\text { Robin Searle } \\
\text { Alan Thompson } \\
\text { Jimmy Springall } \\
\text { Peter Appleyard } \\
\text { Michael Jessop } \\
\text { Thomas Caughie } \\
\text { Pat Fitzgerald } \\
\text { David Graves }\end{array}$ & $\begin{array}{l}\text { Captain } \\
\text { Chief Officer } \\
\text { 2nd Officer } \\
\text { Chief Engineer } \\
\text { 2nd Engineer } \\
\text { 3rd Engineer } \\
\text { Electrician } \\
\text { Bosun } \\
\text { Seaman } \\
\text { Seaman } \\
\text { Seaman } \\
\text { Chief Cook } \\
\text { Second Cook } \\
\text { Steward }\end{array}$ \\
\hline
\end{tabular}

OPERATIONS

The R.V. Farnella, registered in Hull, United Kingdom (U.K.), was used as a research platform for conducting GLORIA and accompanying geophysical surveys. The Farnella is under lease to the U.S. Geological Survey through the Institute of Oceanographic Sciences Deacon Laboratory (IOSDL), Wormley, England. IOSDL personnel are responsible for operations involv- 
ing GLORIA and GLORIA image processing. IOSDL is also in charge of deck operations and maintenance of geophysical gear. Acquisition and processing of navigation data was performed by both USGS and RVS personnel. The USGS personnel monitored the gravimeter, magnetometer, seismic reflection, $3.5 \mathrm{kHz}$ and $10 \mathrm{kHz}$ recording systems. The co-chief scientists coordinated and supervised cruise planning and shipboard operations. Additionally, co-chief scientists produced two GLORIA field mosaics. The results presented here are the initial interpretations and should be considered preliminary observations.

\section{Summary of Field Operations}

The shipboard calendar is presented in Julian Day/Greenwich Mean Time (GMT), for major operations of F2-90-HW . Converting to local Hawaiian time is done by subtracting 10 hours from GMT. Figure 1 is a geographic reference for the region covered by this survey showing bathymetry and trackline coverage.

Day 029 (Monday, January 29)

0000 Shipboard gravity meter was on when we arrived.

1839 Gravity tie of shipboard meter at pier 9, Port of Honolulu

2100 Shoved off Pier 9, Port of Honolulu, weather sunny and choppy seas.

Day 030 (Tuesday, January 30 )

1830 Began deploying gear. Weather clear \& choppy.

Starboard $3.5 \mathrm{kHz}$ system noisy, deployed spare $3.5 \mathrm{kHz}$ fish.

2006 Deploy XBT \#084 T-04

2007 GLORIA tumed on

2242 SOL $-1\left(23^{\circ} 05.65^{\circ} \mathrm{N}, 162^{\circ} 25.66 \mathrm{~W}\right)$

Day 031 (Wednesday, January 31)

1300 EOL $-1\left(22^{\circ} 59.00^{\circ} \mathrm{N}, 164^{\circ} 38.03 \mathrm{~W}\right)$

$1305 \mathrm{SOL}-2\left(22^{\circ} 59.08^{\circ} \mathrm{N}, 164^{\circ} 38.7 \mathrm{~W}\right)$ Weather clear, moderate swell

1719 EOL - $2\left(23^{\circ} 01.57^{\circ} \mathrm{N}, 165^{\circ} 16.50 \mathrm{~W}\right)$

$1728 \mathrm{SOL}-3\left(23^{\circ} 02.01^{\circ} \mathrm{N}, 165^{\circ} 17.78 \mathrm{~W}\right)$

1922 Deploy XBT \#85 T-04

Day 032 (Thursday, February 1)

$\begin{array}{cl}0813 & \text { EOL - } 3\left(23^{\circ} 40.30^{\circ} \mathrm{N}, 167^{\circ} 26.14 \mathrm{~W}\right) \\ 0823 & \mathrm{SOL}-4\left(23^{\circ} 39.63^{\circ} \mathrm{N}, 167^{\circ} 27.25 \mathrm{~W}\right) \\ 1003 & \mathrm{EOL}-4\left(23^{\circ} 26.2^{\prime} \mathrm{N}, 167^{\circ} 31.28 \mathrm{~W}\right) \\ 1012 & \text { SOL }-5\left(23^{\circ} 25.74^{\circ} \mathrm{N}, 167^{\circ} 32.67 \mathrm{~W}\right) \\ 1 & \text { Weather clear, moderate swell } \\ 1707 & \text { Deploy XBT \#86 T-04 }\end{array}$


Day 033 (Friday, February 2)

1845 Deploy XBT \#87 T-04

Weather cloudy, moderate choppy swell

Day 034 (Saturday, February 3)

2036 Deploy XBT \#89 T-04 (\#88 a bust)

2359 Replace 3.5 fish (noisy)

Day 035 (Sunday, February 4)

2023 Deploy XBT \#90 T-04

Weather moderate

Day 036 (Monday, February 5)

04523.5 recorder malfunction

1338 EOL - $5\left(27^{\circ} 47.09^{\prime} \mathrm{N}, 177^{\circ} 46.67^{\circ} \mathrm{E}\right)$

1351 SOL - $6\left(27^{\circ} 48.51^{\circ} \mathrm{N}, 177^{\circ} 45.29^{\circ} \mathrm{E}\right)$

Weather moderately rough, rolling seas

1540 EOL - $6\left(28^{\circ} 04.06^{\circ} \mathrm{N}, 177^{\circ} 43.15^{\circ} \mathrm{E}\right)$

$1553 \mathrm{SOL}-7\left(28^{\circ} 04.79^{\prime} \mathrm{N}, 177^{\circ} 44.41^{\circ} \mathrm{E}\right)$

Heavy seas

Day 037 (Tuesday, February 6)

0155 Problem with GLORIA power--switched amps no data loss

1942 Deploy XBT \#91 T-04

Day 038 (Wednesday, February 7)

0919 EOL - $7\left(26^{\circ} 13.20^{\circ} \mathrm{N}, 175^{\circ} 55.24 \mathrm{~W}\right)$

$0931 \mathrm{SOL}-8\left(26^{\circ} 13.88^{\prime} \mathrm{N}, 175^{\circ} 53.80 \mathrm{~W}\right)$

1100 EOL - $8\left(26^{\circ} 27.11^{\circ} \mathrm{N}, 175^{\circ} 48.89 \mathrm{~W}\right)$

1112 SOL - $9\left(26^{\circ} 28.36^{\prime} \mathrm{N}, 175^{\circ} 49.78 \mathrm{~W}\right)$

Heavy swell, approaching gale forced us to turn back and survey westem field area first.

2200 Swap out $3.5 \mathrm{kHz}$ fish again (noisy!)

2336 Deploy XBT \#92 T-07

Day 039 (Thursday, February 8)

2017 Deploy XBT \#93 T-04 (27 56.8'N, 179 11.3E)

Weather sunny but heavy swell and windy

Day 040 (Friday, February 9)

0604 EOL - $9\left(28^{\circ} 22.15^{\prime} \mathrm{N}, 177^{\circ} 45.12^{\prime} \mathrm{E}\right)$

0614 SOL - $10\left(28^{\circ} 23.41^{\circ} \mathrm{N}, 177^{\circ} 44.01^{\circ} \mathrm{E}\right)$

0749 EOL - $10\left(28^{\circ} 37.67^{\circ} \mathrm{N}, 177^{\circ} 45.23^{\circ} \mathrm{E}\right)$

0802 SOL - $11\left(28^{\circ} 38.57^{\circ} \mathrm{N}, 177^{\circ} 46.72^{\prime} \mathrm{E}\right)$

19003.5 fish replaced and recorder malfunction

Started mosaicking data

Day 041 (Saturday, February 10, Hump Day)

1415 GLORIA depth, pitch and roll sensors temp. down due to seas

1822 Deploy XBT \#95 T-04 (270 04.3`N, 176 54.5W)

1836 Deploy XBT \#96 T-04 (270 03.7'N, $\left.176^{\circ} 52.5 \mathrm{~W}\right)$

2033 EOL $-11\left(26^{\circ} 58.35^{\circ} \mathrm{N}, 176^{\circ} 34.29 \mathrm{~W}\right)$ 
2044 SOL - $12\left(26^{\circ} 57.29^{\circ} \mathrm{N}, 176^{\circ} 33.22 \mathrm{~W}\right)$

Maneuver around Salmon Bank

2246 EOL - $12\left(26^{\circ} 41.46^{\circ} \mathrm{N}, 176^{\circ} 26.16 \mathrm{~W}\right)$

2319 SOL - $13\left(26^{\circ} 42.54^{\circ} \mathrm{N}, 176^{\circ} 26.23 \mathrm{~W}\right)$

Heavy seas

Day 042 (Sunday, February 11)

$\begin{array}{ll}0043 & \text { EOL }-13\left(26^{\circ} 53.55^{\prime} \mathrm{N}, 176^{\circ} 20.47 \mathrm{~W}\right) \\ 0054 & \mathrm{SOL}-14\left(26^{\circ} 53.92^{\prime} \mathrm{N}, 176^{\circ} 18.92 \mathrm{~W}\right) \\ 0353 & \text { EOL }-14\left(26^{\circ} 46.32^{\prime} \mathrm{N}, 175^{\circ} 51.83 \mathrm{~W}\right) \\ 0401 & \mathrm{SOL}-15\left(26^{\circ} 45.47^{\circ} \mathrm{N}, 175^{\circ} 51.22 \mathrm{~W}\right) \\ 0739 & \mathrm{EOL}-15\left(26^{\circ} 15.89^{\circ} \mathrm{N}, 176^{\circ} 01.23 \mathrm{~W}\right) \\ 0750 & \text { SOL }-16\left(26^{\circ} 14.77^{\circ} \mathrm{N}, 176^{\circ} 00.64 \mathrm{~W}\right) \\ & \text { resuming eastern data coverage } \\ 2230 & \text { Problem with solenoid after air-gun servicing }\end{array}$

Day 043 (Monday, February 12)

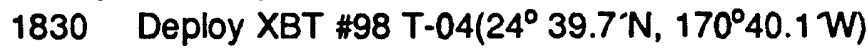

Heavy seas

Day 044 (Tuesday, February 13)

1615 EOL - $16\left(23^{\circ} 38.91^{\circ} \mathrm{N}, 167^{\circ} 20.68 \mathrm{~W}\right)$

1625 SOL - $17\left(23^{\circ} 39.37^{\prime} \mathrm{N}, 167^{\circ} 19.49 \mathrm{~W}\right)$

1802 EOL $-17\left(23^{\circ} 52.65^{\circ} \mathrm{N}, 167^{\circ} 14.82 \mathrm{~W}\right)$

1812 SOL - $18\left(23^{\circ} 53.81^{\circ} \mathrm{N}, 167^{\circ} 15.43 \mathrm{~W}\right)$

1822 Deploy XBT \#99 T-04(23 $\left.54.3^{\circ} \mathrm{N}, 167^{\circ} 17.0 \mathrm{~W}\right)$

Heavy seas

Day 045 (Wednesday, February 14)

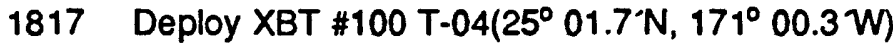

Day 046 (Thursday, February 15)
0009 EOL - $18\left(25^{\circ} 18.65^{\circ} \mathrm{N}, 171^{\circ} 56.96 \mathrm{~W}\right)$
0018 SOL - $19\left(25^{\circ} 18.30^{\circ} \mathrm{N}, 171^{\circ} 58.40 \mathrm{~W}\right)$
Maneuver around Northhampton Seamounts
0101 EOL - $19\left(25^{\circ} 12.85^{\prime} \mathrm{N}, 172^{\circ} 02.84 \mathrm{~W}\right)$
0111 SOL - $20\left(25^{\circ} 12.47^{\circ} \mathrm{N}, 172^{\circ} 04.18 \mathrm{~W}\right)$
$0253 \mathrm{EOL}-20\left(25^{\circ} 23.64 \mathrm{~N}, 172^{\circ} 16.01 \mathrm{~W}\right)$
$0259 \mathrm{SOL}-21\left(25^{\circ} 23.83^{\prime} \mathrm{N}, 172^{\circ} 16.23 \mathrm{~W}\right)$
0420 EOL $-21\left(25^{\circ} 19.26 \mathrm{~N}, 172^{\circ} 29.61 \mathrm{~W}\right)$
0439 SOL - $22\left(25^{\circ} 18.59^{\circ} \mathrm{N}, 172^{\circ} 28.65 \mathrm{~W}\right)$
0554 EOL $-22\left(25^{\circ} 28.92^{\prime} \mathrm{N}, 172^{\circ} 32.77 \mathrm{~W}\right)$
$0601 \mathrm{SOL}-23\left(25^{\circ} 29.63^{\prime} \mathrm{N}, 172^{\circ} 33.50 \mathrm{~W}\right)$
1345 EOL - $23\left(25^{\circ} 51.64^{\circ} \mathrm{N}, 173^{\circ} 46.39 \mathrm{~W}\right)$
$1354 \mathrm{SOL}-24\left(25^{\circ} 51.56^{\circ} \mathrm{N}, 173^{\circ} 47.92^{\prime} \mathrm{W}\right)$
Maneuver around Lisianski Is.
1502 EOL - $24\left(25^{\circ} 44.79^{\circ} \mathrm{N}, 173^{\circ} 55.20 \mathrm{~W}\right)$
$1525 \mathrm{SOL}-25\left(25^{\circ} 44.12^{\prime} \mathrm{N}, 173^{\circ} 54.03 \mathrm{~W}\right)$
1739 EOL - $25\left(25^{\circ} 57.82^{\prime} \mathrm{N}, 174^{\circ} 08.80 \mathrm{~W}\right)$
$1741 \mathrm{SOL}-26\left(25^{\circ} 58.08^{\prime} \mathrm{N}, 174^{\circ} 09.16 \mathrm{~W}\right)$ 
1827 Deploy XBT \#101 T-04(2600.1'N, $\left.174^{\circ} 15.8 \mathrm{~W}\right)$

Day 047 (Friday, February 16)

$$
\begin{aligned}
& 0542 \text { EOL - } 26\left(26^{\circ} 32.61^{\circ} \mathrm{N}, 176^{\circ} 02.33 \mathrm{~W}\right) \\
& 0552 \text { SOL }-27\left(26^{\circ} 33.77^{\prime} \mathrm{N}, 176^{\circ} 02.96 \mathrm{~W}\right) \\
& 0725 \text { EOL }-27\left(26^{\circ} 46.99^{\prime} \mathrm{N}, 175^{\circ} 58.61 \mathrm{~W}\right) \\
& 0735 \text { SOL - } 28\left(26^{\circ} 47.61^{\circ} \mathrm{N}, 175^{\circ} 57.43 \mathrm{~W}\right) \\
& 1553 \text { EOL - } 28\left(26^{\circ} 23.21^{\circ} \mathrm{N}, 174^{\circ} 36.84 \mathrm{~W}\right) \\
& 1600 \text { SOL }-29\left(26^{\circ} 23.24^{\circ} \mathrm{N}, 174^{\circ} 35.81 \mathrm{~W}\right) \\
& \text { Maneuver around Lisianski and Pioneer Bank } \\
& 1634 \text { EOL - } 29\left(26^{\circ} 27.20^{\circ} \mathrm{N}, 174^{\circ} 32.28 \mathrm{~W}\right) \\
& 1658 \text { SOL - } 30\left(26^{\circ} 27.31^{\circ} \mathrm{N}, 174^{\circ} 33.76 \mathrm{~W}\right) \\
& \left.1811 \text { Deploy XBT \#102 T-07(26 } 24.5^{\circ} \mathrm{N}, 174^{\circ} 22.3 \mathrm{~W}\right) \\
& 2230 \text { Change } 3.5 \mathrm{kHz} \text { fish again (noisy) }
\end{aligned}
$$

Day 048 (Saturday, February 17)

$$
\begin{aligned}
& 0050 \text { EOL }-30\left(26^{\circ} 09.26^{\circ} \mathrm{N}, 173^{\circ} 18.60 \mathrm{~W}\right) \\
& 0105 \mathrm{SOL}-31\left(26^{\circ} 07.59 \mathrm{~N}, 173^{\circ} 17.00 \mathrm{~W}\right) \\
& 0211 \text { EOL }-31\left(25^{\circ} 58.31^{\circ} \mathrm{N}, 173^{\circ} 12.66 \mathrm{~W}\right) \\
& 0214 \text { SOL - } 32\left(25^{\circ} 57.91 \mathrm{~N}, 173^{\circ} 12.28 \mathrm{~W}\right)
\end{aligned}
$$

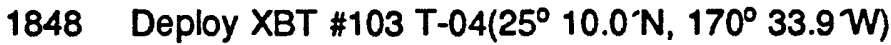

$$
\begin{aligned}
& 2229 \text { Replace } 3.5 \text { fish }
\end{aligned}
$$

Day 049 (Sunday, February 18)

0341 Replaced tape drive on the MASSCOMP

0713 Guns down due to hose puncture after servicing

1558 EOL $-32\left(24^{\circ} 13.81^{\circ} \mathrm{N}, 167^{\circ} 28.95 \mathrm{~W}\right)$

1606 SOL - $33\left(24^{\circ} 14.19^{\prime} \mathrm{N}, 167^{\circ} 28.03^{\circ} \mathrm{W}\right)$

Attempt to survey the gap between Gardner Pinnacles and St. Rogatien Bank-lost GLORIA heading sensor due to heavy seas required course change

1729 EOL - $33\left(24^{\circ} 25.91^{\circ} \mathrm{N}, 167^{\circ} 28.01 \mathrm{~W}\right)$

1741 SOL - $34\left(24^{\circ} 26.74^{\prime} \mathrm{N}, 167^{\circ} 29.66 \mathrm{~W}\right)$

1812 Deploy XBT \#104 T-04(24 $\left.26.7^{\prime} \mathrm{N}, 167^{\circ} 34.7 \mathrm{~W}\right)$

1912 EOL $-34\left(24^{\circ} 26.70^{\circ} \mathrm{N}, 167^{\circ} 44.59 \mathrm{~W}\right)$

1920 SOL - $35\left(24^{\circ} 26.06^{\circ} \mathrm{N}, 167^{\circ} 45.49 \mathrm{~W}\right)$

2002 EOL - $35\left(24^{\circ} 19.80^{\circ} \mathrm{N}, 167^{\circ} 45.55 \mathrm{~W}\right)$

2009 SOL - $36\left(24^{\circ} 18.85^{\prime} \mathrm{N}, 167^{\circ} 45.05 \mathrm{~W}\right)$

2314 EOL - $36\left(24^{\circ} 10.76^{\prime} \mathrm{N}, 167^{\circ} 17.45 \mathrm{~W}\right)$

2322 SOL $-37\left(24^{\circ} 09.88^{\circ} \mathrm{N}, 167^{\circ} 16.72^{\prime} \mathrm{W}\right)$

Heavy seas

Day 050 (Monday, February 19)
0103 EOL - $37\left(23^{\circ} 55.94^{\circ} \mathrm{N}, 167^{\circ} 21.68 \mathrm{~W}\right)$
0113 SOL - $38\left(23^{\circ} 54.78^{\circ} \mathrm{N}, 167^{\circ} 21.19 \mathrm{~W}\right)$


1950 EOL $-38\left(23^{\circ} 05.36^{\circ} \mathrm{N}, 164^{\circ} 35.17 \mathrm{~W}\right)$
2004 SOL - $39\left(23^{\circ} 06.30^{\circ} \mathrm{N}, 164^{\circ} 33.87 \mathrm{~W}\right)$
2240 EOL $-39\left(23^{\circ} 25.04^{\prime} \mathrm{N}, 164^{\circ} 46.69 \mathrm{~W}\right)$
$2246 \mathrm{SOL}-40\left(23^{\circ} 25.57^{\circ} \mathrm{N}, 164^{\circ} 47.38 \mathrm{~W}\right)$ 
Day 051 (Tuesday, February 20)

0546 EOL - $40\left(23^{\circ} 44.91^{\circ} \mathrm{N}, 165^{\circ} 52.73 \mathrm{~W}\right)$

0551 SOL - $41\left(23^{\circ} 45.33^{\prime} \mathrm{N}, 165^{\circ} 53.36 \mathrm{~W}\right)$

Maneuver around French Frigate Shoals

0808 EOL $-41\left(23^{\circ} 58.64^{\circ} \mathrm{N}, 165^{\circ} 09.08 \mathrm{~W}\right)$

0813 SOL $-42\left(23^{\circ} 58.95^{\circ} \mathrm{N}, 165^{\circ} 09.86 \mathrm{~W}\right)$

1205 EOL - $42\left(23^{\circ} 51.68^{\circ} \mathrm{N}, 166^{\circ} 46.66 \mathrm{~W}\right)$

$1213 \mathrm{SOL}-43\left(23^{\circ} 51.92^{\prime} \mathrm{N}, 166^{\circ} 47.91 \mathrm{~W}\right)$

1707 EOL $-43\left(24^{\circ} 21.24^{\circ} \mathrm{N}, 167^{\circ} 25.93 \mathrm{~W}\right)$

End of data collection except gravity \& maggie

1838 Deploy XBT \#106 T-04(24 $\left.21^{\circ} 1^{\circ} \mathrm{N}, 167^{\circ} 25.7 \mathrm{~W}\right)$

Day 052 (Wednesday, February 21)

Transiting to Honolulu

Day 053 (Thursday, February 22)

Transiting to Honolulu

1953 At the dock, end of cruise, gravity land-tie taken

Trackline Summary

The following trackline endpoints were nun for cruise F2-90-HW (fig. 1). Poor weather conditions required us to modify planned tracklines to complete coverage of the western portion of the F2-90-HW mosaic while the weather held. For most of the cruise there were consistently strong winds and heavy swell from the north and east. (Note: SOL = start of line; EOL $=$ end of line)

LINE NO.

LINE 1

LINE 2

LINE 3

LINE 4

LINE 5

LINE 6

LINE 7

LINE 8

LINE 9

LINE 10

LINE 11

LINE 12

LINE 13

LINE 14

LINE 15

LINE 16
SOL $23^{\circ} 05.65^{\prime} \mathrm{N}, 162^{\circ} 25.66 \mathrm{~W}$ $22^{\circ} 59.08^{\prime} \mathrm{N}, 164^{\circ} 38.70 \mathrm{~W}$ $23^{\circ} 02.011^{\prime} \mathrm{N}, 165^{\circ} 17.78 \mathrm{~W}$ $23^{\circ} 39.63^{\circ} \mathrm{N}, 167^{\circ} 27.25 \mathrm{~W}$ $23^{\circ} 25.74^{\circ} \mathrm{N}, 167^{\circ} 32.67^{\prime} \mathrm{W}$ $27^{\circ} 48.51^{\circ} \mathrm{N}, 177^{\circ} 45.29^{\circ} \mathrm{E}$ $28^{\circ} 04.79^{\circ} \mathrm{N}, 177^{\circ} 44.41^{\circ} \mathrm{E}$ $26^{\circ} 13.88^{\circ} \mathrm{N}, 175^{\circ} 53.80 \mathrm{~W}$ $26^{\circ} 28.36^{\prime} \mathrm{N}, 175^{\circ} 49.78 \mathrm{~W}$ $28^{\circ} 23.41^{\circ} \mathrm{N}, 177^{\circ} 44.01^{\top} \mathrm{E}$ $28^{\circ} 38.57^{\prime} \mathrm{N}, 177^{\circ} 46.72^{\circ} \mathrm{E}$ $26^{\circ} 57.29^{\circ} \mathrm{N}, 176^{\circ} 33.22 \mathrm{~W}$ $26^{\circ} 42.54^{\circ} \mathrm{N}, 176^{\circ} 26.23 \mathrm{~W}$ $26^{\circ} 53.92^{\prime} \mathrm{N}, 176^{\circ} 18.92 \mathrm{~W}$ $26^{\circ} 45.47^{\prime} \mathrm{N}, 175^{\circ} 51.22 \mathrm{~W}$ $26^{\circ} 14.77^{\circ} \mathrm{N}, 176^{\circ} 00.64 \mathrm{~W}$
EOL

$22^{\circ} 59.00 \mathrm{~N}, 164^{\circ} 38.03 \mathrm{~W}$ $23^{\circ} 01.57^{\circ} \mathrm{N}, 165^{\circ} 16.50 \mathrm{~W}$ $23^{\circ} 40.30^{\circ} \mathrm{N}, 167^{\circ} 26.14 \mathrm{~W}$ $23^{\circ} 26.20^{\prime} \mathrm{N}, 167^{\circ} 31.28 \mathrm{~W}$ $27^{\circ} 47.09 \mathrm{~N}, 177^{\circ} 46.67^{\circ} \mathrm{E}$ $28^{\circ} 04.06^{\circ} \mathrm{N}, 177^{\circ} 43.15^{\circ} \mathrm{E}$ $26^{\circ} 13.20 \mathrm{~N}, 175^{\circ} 55.24 \mathrm{~W}$ $26^{\circ} 27.11 \mathrm{~N}, 175^{\circ} 48.89 \mathrm{~W}$ $28^{\circ} 22.15 \mathrm{~N}, 177^{\circ} 45.12^{\circ} \mathrm{E}$ $28^{\circ} 37.67 \mathrm{~N}, 177^{\circ} 45.23^{\circ} \mathrm{E}$ $26^{\circ} 58.35 \mathrm{~N}, 176^{\circ} 34.29 \mathrm{~W}$ $26^{\circ} 41.46 \mathrm{~N}, 176^{\circ} 26.16 \mathrm{~W}$ $26^{\circ} 53.55 \mathrm{~N}, 176^{\circ} 20.47 \mathrm{~W}$ $26^{\circ} 46.32 \mathrm{~N}, 175^{\circ} 51.83 \mathrm{~W}$ $26^{\circ} 15.89 \mathrm{~N}, 176^{\circ} 01.23 \mathrm{~W}$ $23^{\circ} 38.91^{\top} \mathrm{N}, 167^{\circ} 20.68 \mathrm{~W}$ 


\begin{tabular}{|c|c|c|}
\hline 17 & $23^{\circ} 39.37^{\circ} \mathrm{N}, 167^{\circ} 19.49 \mathrm{~W}$ & $23^{\circ} 52.65 \mathrm{~N}, 167^{\circ} 14.82 \mathrm{~W}$ \\
\hline 18 & $23^{\circ} 53.81^{\prime} \mathrm{N}, 167^{\circ} 15.43 \mathrm{~W}$ & $25^{\circ} 18.65 \mathrm{~N}, 171^{\circ} 56.96 \mathrm{~W}$ \\
\hline 15 & $25^{\circ} 18.30^{\circ} \mathrm{N}, 171^{\circ} 58.40 \mathrm{~W}$ & $25^{\circ} 12.85 \mathrm{~N}, 172^{\circ} 02.84 \mathrm{~W}$ \\
\hline IE 20 & $25^{\circ} 12.47^{\circ} \mathrm{N}, 172^{\circ} 04.18 \mathrm{~W}$ & $25^{\circ} 23.64 \mathrm{~N}, 172^{\circ} 16.01 \mathrm{~W}$ \\
\hline NE 21 & $25^{\circ} 23.83^{\circ} \mathrm{N}, 172^{\circ} 16.23 \mathrm{~W}$ & $25^{\circ} 19.26 \mathrm{~N}, 172^{\circ} 29.61 \mathrm{~W}$ \\
\hline NE 22 & $25^{\circ} 18.59^{\circ} \mathrm{N}, 172^{\circ} 28.65 \mathrm{~W}$ & $25^{\circ} 28.92 \mathrm{~N}, 172^{\circ} 32.77 \mathrm{~W}$ \\
\hline NE 23 & $25^{\circ} 29.63^{\prime} \mathrm{N}, 172^{\circ} 33.50 \mathrm{~W}$ & $25^{\circ} 51.64 \mathrm{~N}, 173^{\circ} 46.39 \mathrm{~W}$ \\
\hline NE 24 & $25^{\circ} 51.56^{\circ} \mathrm{N}, 173^{\circ} 47.92 \mathrm{~W}$ & $25^{\circ} 44.79 \mathrm{~N}, 173^{\circ} 55.20 \mathrm{~W}$ \\
\hline NE 25 & $25^{\circ} 44.12^{\prime} \mathrm{N}, 173^{\circ} 54.03 \mathrm{~W}$ & $25^{\circ} 57.82 \mathrm{~N}, 174^{\circ} 08.80 \mathrm{~W}$ \\
\hline NE 26 & $25^{\circ} 58.08^{\circ} \mathrm{N}, 174^{\circ} 09.16 \mathrm{~W}$ & $26^{\circ} 32.61 \mathrm{~N}, 176^{\circ} 02.33 \mathrm{~W}$ \\
\hline NE 27 & $26^{\circ} 33.77^{\circ} \mathrm{N}, 176^{\circ} 02.96 \mathrm{~W}$ & $26^{\circ} 46.99 \mathrm{~N}, 175^{\circ} 58.61 \mathrm{~W}$ \\
\hline VE 28 & $26^{\circ} 47.61^{\circ} \mathrm{N}, 175^{\circ} 57.43 \mathrm{~W}$ & $26^{\circ} 23.21 \mathrm{~N}, 174^{\circ} 36.84 \mathrm{~W}$ \\
\hline 9 & $26^{\circ} 23.24^{\prime}$ & $26^{\circ} 27.20 \mathrm{~N}, 174^{\circ} 32.28 \mathrm{~W}$ \\
\hline JE 30 & $26^{\circ} 27.31^{\circ} \mathrm{N}, 174^{\circ} 33.76 \mathrm{~W}$ & $26^{\circ} 09.26 \mathrm{~N}, 173^{\circ} 18.60 \mathrm{~W}$ \\
\hline NE 31 & $26^{\circ} 07.59^{\circ} \mathrm{N}, 173^{\circ} 17.00 \mathrm{~W}$ & $25^{\circ} 58.31 \mathrm{~N}, 173^{\circ} 12.66 \mathrm{~W}$ \\
\hline JE 32 & $25^{\circ} 57.91^{\circ} \mathrm{N}, 173^{\circ} 12.28 \mathrm{~W}$ & $24^{\circ} 13.81 \mathrm{~N}, 167^{\circ} 28.95 \mathrm{~W}$ \\
\hline NE 33 & $24^{\circ} 14.19^{\circ} \mathrm{N}, 167^{\circ} 28.03 \mathrm{~W}$ & $24^{\circ} 25.91 \mathrm{~N}, 167^{\circ} 28.01 \mathrm{~W}$ \\
\hline JE 34 & $24^{\circ} 26.74^{\circ} \mathrm{N}, 167^{\circ} 29.66 \mathrm{~W}$ & $24^{\circ} 26.70 \mathrm{~N}, 167^{\circ} 44.59 \mathrm{~W}$ \\
\hline JE 35 & $24^{\circ} 26.06^{\circ} \mathrm{N}, 167^{\circ} 45.49 \mathrm{~W}$ & $24^{\circ} 19.80 \mathrm{~N}, 167^{\circ} 45.55 \mathrm{~W}$ \\
\hline NE 36 & $24^{\circ} 18.85^{\circ} \mathrm{N}, 167^{\circ} 45.05 \mathrm{~W}$ & $24^{\circ} 10.76 \mathrm{~N}, 167^{\circ} 17.45 \mathrm{~W}$ \\
\hline NE 37 & $24^{\circ} 09.88^{\circ} \mathrm{N}, 167^{\circ} 16.72 \mathrm{~W}$ & $23^{\circ} 55.94^{\circ} \mathrm{N}, 167^{\circ} 21.68 \mathrm{~W}$ \\
\hline NE 38 & $23^{\circ} 54.78^{\circ} \mathrm{N}, 167^{\circ} 21.19 \mathrm{~W}$ & $23^{\circ} 05.36 \mathrm{~N}, 164^{\circ} 35.17 \mathrm{~W}$ \\
\hline NE 39 & $23^{\circ} 06.30^{\circ} \mathrm{N}, 164^{\circ} 33.87 \mathrm{~W}$ & $23^{\circ} 25.04 \mathrm{~N}, 164^{\circ} 46.69 \mathrm{~W}$ \\
\hline 40 & $23^{\circ} 25.57^{\circ} \mathrm{N}, 164^{\circ} 47.38 \mathrm{~W}$ & $23^{\circ} 44.91 \mathrm{~N}, 165^{\circ} 52.73 \mathrm{~W}$ \\
\hline 41 & $23^{\circ} 45.33^{\prime} \mathrm{N}, 165^{\circ} 53.36 \mathrm{~W}$ & $23^{\circ} 58.64 \mathrm{~N}, 165^{\circ} 09.08 \mathrm{~W}$ \\
\hline & $23^{\circ} 58.95^{\circ} \mathrm{N}, 165^{\circ} 09.86 \mathrm{~W}$ & $23^{\circ} 51.68 \mathrm{~N}, 166^{\circ} 46.66 \mathrm{~W}$ \\
\hline NE 4 & $23^{\circ} 51.92^{\prime} \mathrm{N}, 166^{\circ} 47.91 \mathrm{~W}$ & $24^{\circ} 21.24 \mathrm{~N}, 167^{\circ} 25.93 \mathrm{~W}$ \\
\hline
\end{tabular}

\section{Equipment Summary}

Equipment employed for shipboard data collection is described below. Detailed compilation of shipboard data collection and performance of equipment is recorded in the DAFE database for F2-90-HW. Appendix I summarizes standard operational procedures established during the 1986 surveys (Normark et al., 1987 and 1989).

\section{Gravity Meter}

The gravity meter, a LaCoste and Romberg S-53, functioned continuously for the entire cruise. A land-sea gravity tie was established at pier 9 in Honolulu before departure. Another land-sea gravity tie was established following the cruise so that dritt corrections could be applied to the data. Gravity was recorded on magnetic tape and a strip-chart recorder. 


\section{Magnetometer}

The magnetometer was deployed on Day $030 / 1830$ hrs. The data are recorded on both strip-chart and magnetic tape along with the gravity data. There were no serious problems with the system other than XBT wire on the sensor, which was retrieved to remove the wire. The magnetometer was recovered on Day $051 / 1707$ hrs.

\section{Expendable Bathythermographs (XBT's)}

XBT probes were deployed once daily, to measure the thickness of the ocean surface mixed layer, and the thermocline temperature profile. Occasionally, XBT drops were canceled or failed due to excessive wind or ship motion. Two types of profiles were used: T-04 probes, capable of profiling to $460 \mathrm{~m}$, and T-07 XBT's that can profile to $760 \mathrm{~m}$. T-07 probes were generally deployed weekly while T-04 probes were used for the intervening 6 days. The system consists of an XBT launcher and receiver, a GOES satellite transmitter, and a microcomputer/controller for recording, data output, and data transmission, and performed well except for consistent data spikes at about $80 \mathrm{~m}$ and later at $320 \mathrm{~m}$, apparently generated in the recording system and not the XBT's themselves. The probe was launched using a 4 foot extension handie mostly from the port side of the vessel, $20^{\circ}$ forward of the stern. The following list is a record of the location of daily XBT drops.

\section{XBT DROPS}

\begin{tabular}{|c|c|c|c|c|c|}
\hline DAY & NUMBER & TYPE & $\begin{array}{c}\mathrm{H}_{2} \mathrm{O} \text { DEPTH } \\
(M)\end{array}$ & LATITUDE & LONGITUDE \\
\hline 030 & 84 & T-04 & 3280 & $23^{\circ} 16.4^{\circ} \mathrm{N}$ & $162^{\circ} 06.6 \mathrm{~W}$ \\
\hline 031 & 85 & $T-04$ & 4250 & $23^{\circ} 06.9^{\circ} \mathrm{N}$ & $165^{\circ} 34.8 W$ \\
\hline 032 & 86 & T-04 & 4865 & $23^{\circ} 43.1^{\circ} \mathrm{N}$ & $168^{\circ} 30.5 \mathrm{~W}$ \\
\hline 033 & 87 & T-04 & 4110 & $24^{\circ} 50.2^{\prime} \mathrm{N}$ & $172^{\circ} 09.4 W$ \\
\hline 034 & 89 & T-04 & 5180 & $25^{\circ} 49.1^{\circ} \mathrm{N}$ & $175^{\circ} 57.2 W$ \\
\hline 035 & 90 & $T-04$ & 5325 & $27^{\circ} 01.3^{\circ} \mathrm{N}$ & $179^{\circ} 48.3 W$ \\
\hline 037 & 91 & $\mathrm{~T}-04$ & 5115 & $26^{\circ} 45.1^{\circ} \mathrm{N}$ & $178^{\circ} 10.5 W$ \\
\hline 038 & 92 & $\mathrm{~T}-07$ & 4955 & $26^{\circ} 54.6^{\circ} \mathrm{N}$ & $177^{\circ} 58.4 W$ \\
\hline 039 & 93 & $\mathrm{~T}-04$ & 5250 & $27^{\circ} 56.8^{\prime} \mathrm{N}$ & $179^{\circ} 11.3^{\prime} \mathrm{E}$ \\
\hline
\end{tabular}




$\begin{array}{lcclll}041 & 95 & \text { T-04 } & 3470 & 27^{\circ} 04.3^{\circ} \mathrm{N} & 176^{\circ} 54.5 \mathrm{~W} \\ 041 & 96 & \text { T-04 } & 2800 & 27^{\circ} 03.7^{\circ} \mathrm{N} & 176^{\circ} 52.5 \mathrm{~W} \\ 042 & 97 & \text { T-04 } & 3400 & 25^{\circ} 45.5^{\prime} \mathrm{N} & 174^{\circ} 21.5 \mathrm{~W} \\ 043 & 98 & \text { T-04 } & 4760 & 24^{\circ} 39.7^{\prime} \mathrm{N} & 170^{\circ} 40.1 \mathrm{~W} \\ 044 & 99 & \text { T-04 } & 4770 & 23^{\circ} 54.3^{\circ} \mathrm{N} & 167^{\circ} 17.0 \mathrm{~W} \\ 045 & 100 & \text { T-04 } & 4360 & 25^{\circ} 01.7^{\circ} \mathrm{N} & 171^{\circ} 00.3 \mathrm{~W} \\ 046 & 101 & \text { T-04 } & 2800 & 26^{\circ} 00.1^{\circ} \mathrm{N} & 174^{\circ} 15.8 \mathrm{~W} \\ 047 & 102 & \text { T-07 } & 4198 & 26^{\circ} 24.5^{\prime} \mathrm{N} & 174^{\circ} 22.3 \mathrm{~W} \\ 048 & 103 & \text { T-04 } & 1810 & 25^{\circ} 10.0^{\circ} \mathrm{N} & 170^{\circ} 33.9 \mathrm{~W} \\ 049 & 104 & \text { T-04 } & 3200 & 24^{\circ} 26.7^{\circ} \mathrm{N} & 167^{\circ} 34.7 \mathrm{~W} \\ 050 & 105 & \text { T-04 } & 3750 & 23^{\circ} 09.7^{\circ} \mathrm{N} & 164^{\circ} 49.5 \mathrm{~W} \\ 051 & 106 & \text { T-04 } & 4300 & 24^{\circ} 21.1^{\circ} \mathrm{N} & 167^{\circ} 25.7 \mathrm{~W}\end{array}$

3.5-kHz High-Resolution Profiling System

The 3.5-kHz seismic-reflection tow fish was deployed on Day 030/1937 hrs. Problems with record quality began within the first few days of the cruise. On Day 034 the tow fish was replaced. However, record quality remained about the same. On Day 036 the stylus belt on the recorder lost synchronization and started shredding recording paper. The recorder continued to tear the record intermittently over the rest of the cruise. Each time the machine malfunctioned, the system would be down for 2-3 minutes. On Day 038 the drive motor was cleaned. Degrading record quality on Day 038 lead us to exchange the tow fish again, resulting in a decrease in noise content. On Days 040 and 046 the recorder lost synchronization again. On Day 047 the tow fish was again replaced because of poor record quality, however, record quality remained poor. On Day 048 the fish was repaired and replaced, resulting in improved record quality. The tow fish was recovered at Day 051/1707 hrs.

\section{0-kHz Echo-Sounding System}

The 10-kHz echo-sounding tow fish was deployed on Day 030/1916 hrs. The system worked well, with down time only for routine maintenance. The tow fish was recovered at Day $051 / 1707$ hrs. 


\section{Two-Channel Seismic-Reflection System}

The two-channel seismic-reflection system employs a $2600 \mathrm{~cm}^{3}\left(160 \mathrm{in}^{3}\right)$ air-gun sound source, and an $800 \mathrm{~m}$ weight-stabilized two-channel streamer. Two $50 \mathrm{~m}$ long transducer sections are towed 500 to $600 \mathrm{~m}$ behind the air-gun which is fired every 10 seconds. Two-channel data is recorded real time on a MASSCOMP computer and displayed on a graphics monitor set to receive a one-channel, 2.3-second analog record. Two, single-channel analog hard copy records are produced on Raytheon line scan recorders (LSR), one 8 seconds and one 6 seconds in length. The memory function on the six second record was used to print at a constant orientation (west and north are on the left, east and south are on the right). At a speed of 8.5 knots, vertical exaggeration is about $4: 1$ on the 6 second record and about 20:1 on the 8 second record. The MASSCOMP computer crashed several times during the cruise owing to system errors. During the last week, problems were experienced with the change over between tape drives and bringing the 01 drive on line following line changes. In the former case, the tape would write 20 to 700 shots to tape and then unwind tape inside the drive. The latter case resulted in the load and high density lights flashing. On Day 49 the 01 drive was replaced.

The two-channel seismic-reflection system was deployed on Day 030/2110 hrs. No problems with the streamer were experienced during the cruise. The air-guns required routine maintenance 3 times during the cruise. A problem with the solenoid (Day 042) occurred after the second servicing and shortly after the third (Day 049) an air hose developed a puncture. Final recovery was at Day $051 / 1707$ hrs.

\section{Navigation Systems}

Shipboard positioning consists of two navigation systems. The first system called the $A B C$ system, is operated by RVS and is described in detail by Normark et al. (1987). The ABC system is now used to record navigation, piece together the alternate types of navigation fixes to produce the final "best navigation" computer file. The system then merges the final navigation data with the geopotential and bathymetric data to produce plots, graphs, printouts and tapes of the different data types. 
The second system is the USGS in-house navigation system that is described briefly here and in more detail by Gann (1988). The USGS system consists of a navigation program that runs a real time graphic steering display using an IBM PC XT. Two monitors display the steering information. One monitor is located on the bridge where it is used for steering and one is located in the geophysics lab where progress is monitored and navigation sensors are selected. The navigation program processes Loran signals from a Northstar 7000 receiver to do direct ranging on Loran stations (rhorho navigation), and also receives Global Positioning System (GPS) fixes from a Trimble 4000 receiver. GPS is the most accurate and was available for 21 hours/day for most of the cruise and almost 24 hours/day during the last week. Rhorho is generally the selected navigation aid when GPS is not available however, for the first half of the trip, rhorho wandered and transit satellite fixes with dead reckoning between were used for the final navigation when GPS was down. During this cruise the USGS navigation program was modified to continuously send horho fixes as well as GPS and selected sensor data to the ABC system for processing.

\section{GLORIA Long Range Side-scan Sonar System}

The GLORIA vehicle was launched on Day 030/1955 hrs and data recording started at 2007. On Day $037 / 0155$ hrs the No. 5 starboard pulse power amplifier failed due to a malfunctioning protection circuit. The problem was quickly remedied, without loss of data, by switching in another amplifier. On Day $041 / 1415$ hrs the signals from the vehicle's depth, pitch and roll sensors failed after heading several hours into a heavy swell. A new line was occupied to reduce the stress on the tow cable and all sensors were again operable. Heading into heavy seas on Day 049 again stressed the vehicle tow cable resulting in intermittent readings from the vehicle heading sensor. The loss of heading data degraded the GLORIA images and the line was aborted and a calmer course selected. Fortunately, there was no further loss of data on any of the following survey lines.

To avoid spurious echo retums, signal transmission was suspended during course changes. The system operated continuously until the termination of the survey at Day 051/1707 
hrs, when GLORIA was recovered.

The deployment and operation of the GLORIA system is covered in detail in IOS GLORIA logs. Technical descriptions of the GLORIA system are available in Somers et al. (1978) and Laughton (1981). A summary of the GLORIA pass record and the number of files is presented in Appendix 2. Note that one pass equals 6 hours.

\section{GLORIA Shipboard Image Processing}

The techniques employed in shipboard processing are described in detail in Normark et al. (1987 and 1989). Problems with identical exposure times producing lighter or darker prints were intermittently experienced during the development and printing of the passes during the entire cruise. Wom plastic gears in the timer box are believed to be the cause of the variation. Special shading techniques, such as those used by Normark et al.(1989), were not applied. Following the photo printing of the GLORIA passes, the images were laid down over corrected and smoothed navigation plots and mosaicked. 


\section{RESULTS}

The following outline organizes the topics addressed:

1. Characterization of seismic-reflection data

1a. Reflector characteristics on $3.5 \mathrm{kHz}$ profiles

1b. Reflector characteristics on air-gun profiles

2. Cretaceous seafloor and volcanic features

2a. Seafloor spreading fabric

2b. Murray Fracture Zone

2c. Lava flows

2d. Volcanic ridges

2e. Rift zones

3. Sedimentation

3a. Bedforms

3b. Submerged terraces

3c. Canyons and gullies

4. Mass wasting features

4a. Debris avalanches

4b. Slides

4c. Progressive slumps

Characterization of Seismic-Reflection Data

1a. Reflector characteristics on $3.5 \mathrm{kHz}$ profiles

The sediment cover seen on $3.5 \mathrm{kHz}$ profiles is classified into 5 distinct units; 1) a transparent layer, 2) hyperbolic reflectors, 3) a prolonged reflector, 4) a stratified unit, and 5) an opaque reflector. 
The transparent layer is characterized by a short moderate to strong water bottom reflection, with thickness ranging from 5 to $50 \mathrm{~ms}$ (fig. 2). Occasionally, this layer is internally stratified with a few discontinuous reflectors. This sequence is most prominent at the southern outer fringes of the survey area and over the seafloor spreading fabric in the west where it drapes the horst and grabens with 10 to $50 \mathrm{~ms}$ of sediment (fig. 2). The relatively thick uninterrupted nature of this unit suggests that it is primarily pelagic, and is occasionally interbedded with a thin ash layer or lense. This unit typically overlies the probnged or hyperbolic reflectors.

Irregular, overlapping hyperbolas with widely varying vertices constitute the second reflector type (fig. 3). Hyperbolics found over sedimentary features such as landslide deposits are poor to moderately reflective; the subbottom reflection is either absent or stratified. Occasionally, these hyperpolea are draped by the transparent layer. Hyperbolics found over volcanic bedrock are moderate to highly reflective and the subbottom reflection is opaque. Generally, the latter are not draped by sediment.

The prolonged reflector is characterized by a semi-prolonged to prolonged, fuzzy to sharp, moderate to strong reflection (fig. 4). Occasionally, the prolonged reflector is interrupted by very thin or faint stratification suggesting the sequence is likely composed of highly reflective volcaniclastic material, derived from the Hawaiian Ridge. Rapid deposition, strong bottom currents or erosion have kept this sequence homogenious, devoid of the transparent pelagic layer during deposition. Deposits found close to the Hawailan Ridge appear to have little if any transparent drape suggesting active bottom currents or a consistent source of volcaniclastics. However, farther away from the ridge (near the seafloor spreading fabric) the prolonged reflector is covered by up to $40 \mathrm{~ms}$ of transparent drape.

The stratified unit varies from numerous sharp, high frequency, parallel reflections to several sub-parallel, semi-prolonged reflections (fig. 5). This sequence is located only in the more distal regions of the survey area south and west of the Hawailan Ridge and in deep basins. Thickness ranges from 10 to $40 \mathrm{~ms}$. The primary depositional agents are probably turbidity and bottom currents (Wallin, 1982). This unit gradually grades into a discontinuous, stratified 
unit or with decrease in bed thickness into the prolonged layer.

The opaque reflector is extremely prolonged, very diffuse and generally lacks a distinct upper surface (fig. 6). This unit is only visible in the far northwestern corner of the survey area, over near surface lava flows, and beneath hyperbolic reflections found over volcanic basement. Hence, the origin of this unit appears to be volcanic basement rock and/or lava flows.

1b. Reflector characteristics on air-gun profiles

The air-gun profiles exhibit two general reflection signatures within the survey area: 1) hyperbolic reflectors and highly reflective sequences, and 2) horizontal, highly stratified layers, generally filling areas of low relief.

In areas of rough topography and basement outcrops the reflectors are characterized by multiple hyperbolic returns, presumably from short discontinuous reflectors and by highly reflective returns that often generate several multiples (typical on the Hawaiian Ridge). Generally, these reflectors are interpreted as echoes from igneous rocks and correlate with features of high-backscatter on the GLORIA imagery, which, are identified as either as volcanic seamounts, lava flows, or volcanic basement rocks of the Hawailan Ridge.

The second reflector type is horizontal and well-stratified, filling areas of low relief. The reflectors truncate against steep basement structures rather than drape them. The sequence is likely composed of volcanogenic turbidites and hemipelagic deposits derived from the Hawailan Ridge or from nearby seamounts.

\section{Cretaceous Seafloor and Volcanic Features}

\section{2a. Seafloor Spreading Fabric}

Cretaceous seafloor spreading fabric is faintly imaged in the westernmost portion of the survey area beyond $180^{\circ}$ longitude (fig. 7a). The characteristic horst and graben structures appear on the GLORIA images as faint, high and low-backscatter linear streaks that can be traced up to $45 \mathrm{~km}$, and are spaced from 1 to $30 \mathrm{~km}$ apart. Sediment cover is as great as 40 
ms $(30 \mathrm{~m})$, which accounts for the subtle contrast in the images. The horsts trend $340^{\circ}$ and offsets range between 10 to $100 \mathrm{~m}$ (fig. 2). The fabric can be traced obliquely about $250 \mathrm{kilom}$ eters across the survey area, covering over $30,000 \mathrm{~km}^{2}$.

East of $180^{\circ}$, the horst and graben fabric is absent on the GLORIA imagery. However, a large bedform field is visible on the imagery just east of $180^{\circ}$ (fig. $7 \mathrm{~b}$ ). These bedtorms trend parallel to the adjacent horst and graben fabric to the west (see section on bedforms).

The variations in backscatter intensity associated with the spreading fabric may be caused by topographic relief. This is not to say, that changes in the sediment thickness over the individual horsts and grabens significantly effect the backscatter contrast as suggested by Kayen et al. (1990). However, the sediment thickness present in this area (up to $30 \mathrm{~m}$ or $40 \mathrm{~ms}$ ) only serves to reduce the backscatter contrast between high and low areas. We do not see long continuous individual horsts that can be traced for over $45 \mathrm{~km}$. We believe this to be consistent with what is seen on GLORIA data north of the island of Hawaii. North of the Hawaiian Ridge the lineations are seen as continuous very high-backscatter, high contrast structures that are $\mathbf{5 0}$ $\mathrm{km}$ or less in length. We feel that the inability to map these individual features for long distances may be caused by changes in offsets due to warping and buckling along the faults.

Magnetic anomalies across the western survey area match anomaly chrons M1 to M5 (about 120 to $130 \mathrm{Ma}$ )(Atwater and Severinghaus, 1989). The anomalies extend between $178^{\circ}$ $W$ and $177^{\circ} 40^{\circ} \mathrm{E}$ and $26^{\circ} 30^{\circ} \mathrm{N}$ and $28^{\circ} 30^{\circ} \mathrm{N}$, and include the area of horst and graben structures as well as the adjacent region between $180^{\circ}$ and $178^{\circ} \mathrm{W}$, where the horst and graben structures are not evident. Examination of seismic-reflection profiles suggests that the oceanic crust east of $180^{\circ}$ is smoother, unlike the pronounced horst and graben structure of the crust to the west. The difference between the two crustal types may be caused by an increase in spreading rate for the eastern region. 
2b. Murray Fracture Zone (MFZ)

GLORIA images north and south of the survey area (cruises F12-89-HW, F13-89-HW, F190-HW, and F10-91-HW) show the MFZ trends $255^{\circ}$ and should intersect Northhampton Seamounts. The only likely evidence of the MFZ on the GLORIA images is a faint lineation that extends for $33 \mathrm{~km}$ on the southern edge of the survey area between $173^{\circ} 15^{\prime} \mathrm{W}$ and $173^{\circ} 35^{\prime} \mathrm{W}$ (fig. 7d). This lineation is directly in line with those mapped to the north and south and also trends $255^{\circ}$. Air-gun records collected just north of the image show that it trends towards a thick (0.6 s) sedimentary basin.

\section{2c. Lava flows}

Lava flows are found in the central portion of the survey area (fig. $7 b, 7 c$ and $7 d$ ). The flows commonly have irregular boundarys and little or no relief similar to those imaged on the North Arch flows north of Oahu (Clague et al., 1989; Normark et al., 1989; Clague et al., 1990). Acoustically, the flows show a weak, opaque reflection on $3.5 \mathrm{kHz}$ profiles that are defined by abrupt lateral boundaries. Most of the flows imaged appear on the GLORIA mosaic as faint, mottled, high-backscatter features unlike the younger flows found further to the east(Normark et al., 1989, and Torresan et al., 1989). This difference may result from older age, thicker sedjment cover, sediment composition, flow thickness, and to some extent problems experienced developing the GLORIA photographs (see section on GLORIA Shipboard Image Processing).

West of Lisianski Island lies the largest flow imaged, about $5600 \mathrm{~km}^{2}$ in area (fig. 7c). The possible origin and total extent of the flow is masked by numerous large mass wasting features deposited on top of and east of the flow. The travel path is predominately westward through hummocky terrain, and follows a moderate topographic slope to the west. The flow is shown on GLORIA imagery as a mottled, medium to high-backscatter feature, having irregular boundaries and many lobes. Near the landslide deposits, the lava flow is imaged through $25 \mathrm{~ms}$ of sediment cover. The distal lobes are more visible on the GLORIA images and also have less sediment cover (about $10 \mathrm{~ms}$ ). 
Up to $30 \mathrm{~ms}$ of transparent sediment overlies the lava flow east of south-Northhampton rift obscuring its extent and margins (fig. 7d). The one crossing of the feature on line 5 shows that the flow occupies a structural depression. It is unclear if the flow extends further to the west. GLORIA imagery west of the flow shows a mottled mixture of high and low-backscatter, and the seismic profile displays a hummocky, prolonged reflector. The origin of this flow is also unclear. The region north of the flow is dominated by mass wasting features, which may obscure its northern extent. The southern margin lies outside the survey area but does not lead to a clear source. This flow may be a sheet flow emerging from a fissure on the flanks of the rift or from eruptions flowing south from Northhampton Seamount.

South of the pass between Laysan Island and Maro Reef resides another faint medium to high-backscatter feature on GLORIA that we interpret to be a lava flow (fig. 7d). The feature lies between lines 16 and 18 and does not cross a geophysical trackline, therefore the acoustic character and overlying sediment thickness is unknown. Numerous landslide blocks (up to $2 \mathrm{~km}$ wide) are littered over roughly half of the $1000 \mathrm{~km}^{2}$ flow. The source of the flows may be two small seamounts imaged adjacent to the flow or it is hidden by mass wasting deposits to the west.

The last flow feature is interpreted as a channelized lava flow trending $225^{\circ}$, situated south of Maro Reef (fig. 7d). The channel extends for over $70 \mathrm{~km}$ and is 6 to $8 \mathrm{~km}$ wide. At the terminus of the channel, the flow makes a sharp southeasterly bend and fans into 3 major lobes. GLORIA imagery shows the central channel flows as high-backscatter crenulations. $3.5 \mathrm{kHz}$ profiles show that the channel is shallow and broad ranging from $60 \mathrm{~m}$ deep and $6 \mathrm{~km}$ wide on line 18 , and $15 \mathrm{~m}$ deep and $8 \mathrm{~km}$ wide further south on line 16 . Acoustically, the crossing on line 18 shows small hyperbolic reflections, and on line 16 the reflections are weak but opaque. The imagery of the 3 major distal lobes is faint. The 2 southernmost lobes appear on GLORIA images as mottled but higher-backscatter than the northern lobe. One crossing of the southernmost lobe on line 5 show weak opaque reflections partly capped and bounded to the east and west by prolonged reflectors. The northern lobe is significantly different in appearance. The 
image appears as high-backscatter streaks that branch out in long sinuous fingers. No tracklines cross the northern lobe, and its appearance suggests a more sedirnentary origin. Acoustic evidence for the rest of the feature suggests an igneous origin that may or may not overlie or be overlain by turbidites. The channelized flow appears to overlie a blocky landslide deposit. Covered blocks may be responsible for the crenulated appearance of the channelized flow. These crenulations may result from other flow features, or sediment gravity flow deposits.

\section{2d. Volcanic Ridges}

\section{Necker Ridge}

The northem end of Necker Ridge is imaged in the eastern corner of the survey area, south of Necker Island (fig. 7f). The ridge is up to $15 \mathrm{~km}$ wide and is irnaged along its length for $90 \mathrm{~km}$. Seismic profiles show the ridge to rise $1300 \mathrm{~m}$ above the surrounding seafloor. One central axis volcanic cone is imaged $25 \mathrm{~km}$ south of its northem end.

The origin of Necker Ridge remains unknown. The linear trend of the ridge suggests that it could be a leaky transform or failed spreading center. Saito and Ozima (1977) recovered an alkalic basalt from the ridge that yielded a date of $82 \mathrm{Ma}$. Since fracture zone volcanism is usually tholeiitic it appears that Necker Ridge is likely a failed spreading center.

\section{2e. Rift Zones}

An impressive feature of this GLORIA data set is the visibility and configuration of the submarine rift zones. Over 20 submarine rift zones have been identified in the GLORIA imagery of the survey area and show that rifts are a significant role in the development of the Hawaiian Ridge (fig. $7 b, c, d, e$ and $f$ ). Generally, the rifts appear on GLORIA imagery as highbackscatter, elongate ridges that have tapered and rounded terminations, and a coarse, pitted, almost blurred texture. The flanks are steep sided and show little if any evidence of mass wasting. Some of the rifts have low-backscatter summits that may represent depressions, fissures or rift zone grabens. 
The following discussion will focus on only the major rifts imaged in the survey area. Specifically, those imaged off Pioneer Bank and Northhampton Seamounts.

\section{Pioneer Bank Rift System}

The southern flank of Pioneer Bank is dominated by three parallel rifts (fig. 7d). The western rift, the largest of the group, extends south from Pioneer Bank for $80 \mathrm{~km}$ and is $15 \mathrm{~km}$ wide, trending $190^{\circ}$. The central rift appears to originate on the east flank of the bank, is visible for $60 \mathrm{~km}$ south of Pioneer Bank, and is $14 \mathrm{~km}$ wide. The northern end of the central rift is separated from the westem rift by $10 \mathrm{~km}$ however, its southern end bends slightly westward and may join the western rift. A few kilometers to the east is the eastern rift that extends $60 \mathrm{~km}$ south of the eastern flank of Pioneer Bank and is $8 \mathrm{~km}$ wide.

\section{Northhampton Seamounts Rift System}

Five rifts are associated with the Northhampton Seamounts (fig. 7d). The two westernmost rifts are the smallest of the group and extend $25 \mathrm{~km}$ to the northwest and $40 \mathrm{~km}$ to the southwest from a central source located at $25^{\circ} 44^{\prime} \mathrm{N}$ and $172^{\circ} 56^{\prime} \mathrm{W}$ (fig. $7 \mathrm{~d}$ ). Extending eastward from the western rifts appears to be a $60 \mathrm{~km}$ long rift zone that trends $100^{\circ}$. The crest of this eastward rift is too shallow to be imaged by GLORIA but the continuous nature of the north and south flanks implies that it too is probably a rift. Extending almost due south from what appears to be the eastem end of the eastward rift lies the southern rift, the largest rift imaged in the study area. The southern rift is at least $25 \mathrm{~km}$ wide and is imaged for $90 \mathrm{~km}$ in the study area and continues for another $10 \mathrm{~km}$ farther south. On the northern flank of the central Northhampton Seamount, situated between the central seamount and Laysan Island, is the last rift of this group. This northernmost rift is imaged for $50 \mathrm{~km}$, is $15 \mathrm{~km}$ wide and trends $130^{\circ}$. 


\section{Sedimentation}

\section{3a. Bedforms}

A large approximately $11,000 \mathrm{~km}^{2}$ bedform field is imaged south of Kure Island and Nero Seamount (Fig. 7d). The field extends roughly $90 \mathrm{~km}$ offshore and is seen along line 9 for 150 km. The Cretaceous seafloor spreading fabric dominates the seafloor west of the field and several large lava flows bound it on the east. The major trend of the bedforms field is the same as the Cretaceous spreading fabric, $340^{\circ}$. The bedforms, in plan view, have sinuous crests, with wavelengths ranging between 10 to $30 \mathrm{~km}$. In cross section, the bedforms range from 10 to 25 $\mathrm{m}$ in height and wavelengths range from 1.5 to $5 \mathrm{~km}$. Along part of line 9 (fig. 8) the bedforms appear to be migrating upslope as evidenced by the deposition of the transparent layer only in the upslope or lee side of the feature. A crossing of line 11 (fig. 9) farther west shows cross bedding completely covered by $10 \mathrm{~ms}$ of the transparent layer showing that these features have also been active in the past.

Little is known about the bottom currents active in this area. $3.5 \mathrm{kHz}$ profiles show the bedforms migrating upslope (figs. 8 and 9). Air-gun profiles show that the basement structure below the bedforms is relatively smooth, contrasting with the rugged features associated with the seafloor spreading fabric imaged to the west. Increased spreading rates can account for the smoother basement observed beneath the bedform field. Perhaps, the smoother seafloor provided an ideal platform for the development and migration of these features.

\section{3b. Submerged Terraces}

The GLORIA imagery shows three areas that may be submerged reef terraces. These areas consist of 3 to 5 narrow bands of high-backscatter on the sonar images. Similar features on Haleakala Ridge off Maui have been imaged by GLORIA (Holmes et al., 1987) and subsequently sampled and identified as coral reefs (Clague et al., 1988; Moore et. al., 1990). Similar features are also visible on sonar images collected on the Kohala Terrace (Moore and Clague, 1988), offshore of the Kona coast of Hawaii (Moore and Clague, 1987), off the east coast of 
Mauna Loa's southwest rift zone (Moore et al., 1990), to the south of the island of Lanai (imaged on cruise F5-86-HW), along the north rift zone of St. Rogatien Bank, and near Necker Island (Torresan et al., 1991).

The first set of terraces is located on the northeast flank of Pioneer Bank (fig. 7d) and consist of a series of 5 terraces, $10 \mathrm{~km}$ in length and $2 \mathrm{~km}$ wide, in roughly $800 \mathrm{~m}$ of water. The second set contains 3 terraces that are over $1 \mathrm{~km}$ wide and extend for over $15 \mathrm{~km}$ along the southeast flank of Maro Reef in 1200 to $1400 \mathrm{~m}$ of water (fig. 7e). The third also consists of 3 terraces that run for $20 \mathrm{~km}$ along the northem flank of La Perouse Pinnacle (fig. 7f) and are 2 $\mathrm{km}$ wide in 600 to $700 \mathrm{~m}$ of water. The only features that are visible on geophysicial lines are those found off La Perouse Pinnacle (line 42), thus, water depths reported for the others are estimates.

Reconstruction of sea surface isotherms back to the Tertiary (Clague and Dalrymple, 1987, modified from Greene et al., 1978) show that surface temperatures were marginal for growth of corals from 5-15 Ma at the latitude of Hawaii and too cold before $15 \mathrm{Ma}$. Sampling, submersible work and subsequent dating of volcanic samples shows that subsidence rates for the islands and glacioeustatic sea-level changes account for the variations in water depths that these features are found (Torresan et al., 1991). Likewise, age, changes in subsidence rates, and sea-level changes are the likely reason these three sites are found at different water depths. Torresan et al. (1991) suggest that these features may also be caused by bryozoan-algal reefs, which tolerate cooler temperatures. Definitive answers to questions like late-stage subsidence rates and surface water characteristics must await sampling.

3c. Canyons and gullies

The upper flanks of the Hawaiian Ridge imaged during this cruise are dominated by numerous canyons and gullies that were probably incised during lower stands of sea level (figs. 7c-7f). GLORIA imagery shows these features as numerous high-backscatter strands that either coalesce downslope to form one main channel (see fig. 7d off Maro Reef) or branch out downslope, forming a dendritic or "birdsfoot" pattern (see fig. 7c off Salmon Bank). These 
features are imaged throughout the Hawaiian Ridge and many are probably still active conduits for the transportation of sediment downslope.

\section{Mass wasting features}

The mass wasting features that have modified the southern flank of the Hawailan Ridge from Necker Island to Kure Island can be divided into two major categories as classified by Varnes (1978): debris avalanches and earth, or rock slides (ie slumps and debris slides, see explanation below). Sometimes the two are superimposed on one another.

Slides are defined as deposits produced by translational or rotational movement along one or several surfaces (Varnes, 1978). Rotational slides are more commonly called slumps and will be referred here as such. Slumps are failures caused by a turning movement about a point or axis producing a surface of nupture that concaves upward (Vames, 1978). Five progressive slumps have been identified in the surveyed area and are addressed in a separate section. The translational slides imaged in the study area are more commonly known as debris slides. In translational slides movement is predominantly along planar or gently undulatory surfaces (Varnes, 1978). These surfaces may be structurally controlled by planes of weakness such as faults and bedding planes or contacts between firm bedrock and overlying detritus. Because little or no data exists parallel to the direction of movement for most of the failures along the Hawaiian Ridge it has been difficult to distinguish between the two types of failures and these features have been referred to as just slides.

There exists a complete gradation from debris slides to debris avalanches as movement becomes much more rapid (Varnes, 1978). In debris slides the moving mass breaks up into smaller and smaller blocks as it progresses toward the base of the slope. However, the movement is usually slow and does not travel far past the base. In debris avalanches, the movement is rapid and likely catastrophic, and the mass actually liquefies, at least in part, and advances well beyond the base of the slope (Varnes, 1978).

The mass wasting deposits imaged in the western Hawaiian Ridge differ from those imaged off the eastern Hawaiian Islands. The eastern islands are dominated by debris 
avalanches whereas the western ridge shows an abundance of slumps and debris slides. It may be that catatrophic failures such as debris avalanches are more active during the younger phases of shield building and as the volcanoes age they fail more gradually and these subsequent failures bury the younger ones.

\section{4a. Debris Avalanches}

Adhering to the classification described above there exists 2 major debris avalanches

found south and west of Necker Island; Lisianski and Gardner debris avalanches. However, a strong possibility exists that some of these failures are buried and are no longer easily recognizable on GLORIA imagery. The Hawaiian Ridge ranges from 10 to over $30 \mathrm{Ma}$ along the surveyed region and subsequent failures and sedimentary deposits likely have buried failures formed earlier. Seismic data coverage collected on this cruise is not sufficient to rule out the possibility that some features interpreted as Cretaceous(?) ridges on Figure 7 could be buried, distal, debris avalanche blocks (ie see fig. 7e west of Gardner debris avalanche).

\section{Lisianski Debris Avalanche}

The largest debris avalanche mapped in the study area is located on the southwest flank of Lisianski Island (fig. 7c). The failure covers roughly $9000 \mathrm{~km}^{2}$ making it the fourth largest failure mapped along the Hawaiian Ridge. Both the north and southwest flanks of the island have failed, however, neither is totally imaged in the study area. Since only the uppermost deposits on the north flank are imaged in the data coverage the following discussion will focus on the southwest failure.

Lisianski debris avalanche is at least $70 \mathrm{~km}$ wide and has traveled over $125 \mathrm{~km}(90 \mathrm{~km}$ are imaged in the survey area). The most distal part of the deposit appears to have traveled up and over bedrock highs suggesting extremely rapid movement and emplacement. Blocks located near the terminus of the failure reach $4 \mathrm{~km}$ across, where as, more proximal blocks reach $8 \mathrm{~km}$ in size. 
Large canyons and gullies are incised into and dominate the upper slopes of the failure. They appear as long, narrow high-backscatter strands on GLORIA imagery and typify most of the island flanks and failure headwalls (Moore et al., 1989; Torresan et al., 1991). To the west the failure overlies a large lava flow. The debris deposits located directly south of the island join and probably overlie Lisianski slump located at the base of the slope (fig. 7d). It is doubtful that this deposit represents one single episode of failure. Three lobes can be identified on the GLORIA imagery and may represent separate failures. On GLORIA imagery, the deposit shows numerous high-backscattered blocks overlying a low-backscatter background. Seismic profiles collected along lines 5, 16 and 26 show hyperbolic reflections from rugged topography occasionally draped by poorly stratified deposits .

\section{Gardner Debris Avalanche}

Extending $110 \mathrm{~km}$ to the southwest of Gardner Pinnacles is Gardner debris avalanche (fig. 7e). Only the southern half is exposed because of the subsequent failure of Gardner slump, which apparently covers this part of Gardner debris avalanche. The landslide is seen on GLORIA imagery to be $85 \mathrm{~km}$ wide making its total area $7000 \mathrm{~km}^{2}$. On GLORIA, the southem half of the debris avalanche shows discreet high-backscatter blocks ranging from 1-2 km in size and less distinct elongate high-backscatter features that may be buried larger blocks, scarps or ridges. The $3.5 \mathrm{kHz}$ profiles along lines 5 and 32 show hyperbolic reflections with $10 \mathrm{~ms}$ and 60 ms of sediment cover respectively. Line 32 also shows a moderate slope to the west.

At least 2 episodes of failure can be mapped on the feature. The preservation of the 90 $\mathrm{km}$ long toe scarp at the base of Gardner slump tells us that the debris avalanche is the older of the two failures (see section on Gardner slump).

\section{4b. Slides}

Varnes (1972), defines slides as deposits produced by translational or rotational movement along one or several surfaces. However, the seismic data coverage of the area is limited and was collected parallel to the ridge and therefore perpendicular to the direction most of the 
failures have travelled. Consequently, for some failures the ability to determine if it was produced by translation or rotation is not possible. If the mode of failure is unknown we call these failures simply slides. If we have data that suggests the failure was rotational we call these failures slumps. Likewise, if the data implies translational movement such as a high concentration of discrete blocks that do not travel far past the base of the slope we refer to these deposits as debris slides.

The majority of the western Hawaiian Ridge imaged in this survey, has failed as slides. Consequently, we focus our discussion below on a few of the most prominent failures.

\section{Maro Slide}

Maro slide is located south of Maro Reef, and is imaged on GLORIA for $55 \mathrm{~km}$ of its length and $45 \mathrm{~km}$ of its width (fig. 7e). The direction of movement is to the south. Bounding the slide on the west, is a moderate size debris slide with blocks up to $4 \mathrm{~km}$ wide. Presently, it is unclear which of the two failures is younger. To the east the slide is bounded by a south trending rift zone. A prominent toe scarp extends for $18 \mathrm{~km}$ along the base of the slide and several small failures radiate from it. North of the slide the coastline is relatively straight and a series of 3 apparent terraces or reefs are visible just north of $25^{\circ} \mathrm{N}$ (fig. $7 \mathrm{e}$ ). The $3.5 \mathrm{kHz}$ profile collected along line 32 shows a prolonged flat retum just north of the terraced zone.

On GLORIA Maro slide has a very "wrinkled" appearance produced by high and lowbackscatter targets that are caused by numerous scarps and/or ridges, separated by sediment filled depressions. $3.5 \mathrm{kHz}$ data collected along line 18 shows hyperbolic returns from two steep sided ridges that are situated on either side of the slide. A definitive classification of this feature is not possible. The slope parallel ridges shown on geophysical profiles suggest that the failure might be translational. However, without a cross-sectional view we have little confidence suggesting a mode of failure. 


\section{Gardner Slump}

Gardner slump is located along the southeastem flank of Gardner Pinnacles and is the largest slump mapped in along the Hawaiian Ridge (fig. 7e). According to Varnes' (1978), this feature is a rock slump. The western side of the slump overlies haff of Gardner debris avalanche (see section on Gardner debris avalanche). GLORIA imagery shows the failure to be $50 \mathrm{~km}$ long, $160 \mathrm{~km}$ wide and covers and area about $8000 \mathrm{~km}^{2}$. The two most striking features of this slump are the prominent toe scarp and the basin produced by the back rotation of the slump block.

The toe scarp is imaged on GLORIA sonargraphs continuously for $90 \mathrm{~km}$ (fig. 7e). The eastern half is imaged looking in the upslope direction and shows the feature as a highbackscatter scarp. The western half was imaged in the downslope direction, giving no return *. from the steep scarp and therefore appears as a low-backscatter crack. Numerous small debris slides are shown radiating from the scarp at the eastern end that probably result from talus and debris shedding off the steep toe scarp.

The back-tilted basin is located on the eastern half of the slump roughly $10 \mathrm{~km}$ south of Gardner Pinnacles. The basin is shown on GLORIA imagery as a $9 \mathrm{~km}$ wide, $55 \mathrm{~km}$ long zone of low-backscatter. On line 32, the headscarp is viewed from the downslope direction and is too steep to give a good return. Likewise, the crown of the slump has rotated far enough downslope, that when viewed from the upslope direction on line 18 , it too is unable to send a good return to GLORIA.

The eastern half of the slump appears to be more coherent than the western side. GLORIA imagery shows the western half has a "wrinkled" appearance of high and lowbackscattered features. Seismic-reflection data along line 18 , shows that the western side has several steep peaks or ridges and the eastern side is far less rugged. This difference is possibly caused by the presense of large blocks previously deposited by the older Gardner debris avalanche. The continuation of the $90 \mathrm{~km}$ toe scarp at the base of the slump into the western half proves that the slump is the younger failure. 


\section{Brooks Slide}

Brooks slide is located on the southwest flank of the ridge joining Brooks Bank and La Perouse Pinnacle. We have termed this feature a slide as defined by Vames (1978) because we are not able to distinguish the mode of failure as rotational or translational or a combination of both. The failure is imaged for $120 \mathrm{~km}$ along the slope and $45 \mathrm{~km}$ downslope. Both northeast and southwestern limits of the failure appear to be bounded by major drainage systems, as shown by the high-backscatter on GLORIA, typical of gullies, chutes, and canyons evident along the whole ridge. South of the failure several buried Cretaceous (?) ridges up to $20 \mathrm{~km}$ long are imaged.

The upper slope of the slide is dominated by canyons and gully systems. On GLORIA the lower half appears "wrinkled" by linear high-backscattered targets. These targets are most likely produced by numerous scarps and/or ridges. The $3.5 \mathrm{kHz}$ profiles along lines 43 and 38 show hyperbolic reflections typical of rugged topography. The terminus of the slide is defined by a discontinuous toe scarp. The toe scarp consists of 4 segments one of which is $35 \mathrm{~km}$ long. The discontinuous nature of the toe scarp may represent separate phases of failure or subsequent removal of portions of the scarp by younger mass wasting events.

\section{4c. Progressive Slumps}

Five progressive slumps, as defined by Varnes(1978), have been mapped in the surveyed area and appear on the lower flanks of Nero Seamount, Salmon Bank, Lisianski Island, east Northhampton Seamount, and Necker Island (fig. 7b-7f). In general, these failures share several distinguishing characteristics. Most of the slumps appear at the base of an unbuttressed flank of an older Hawaiian volcano but are not associated with rift zones. All appear on GLORIA images as alternating high and low-backscatter, narrow, sinuous, and slightly arcuate bands. Some evidence also shows that the failures are only visible on GLORIA imagery if they are covered by at least $10 \mathrm{~ms}$ of transparent sediment. Where available, the data also shows that both fault offsets and sediment cover decreases downslope. Generally, the slumps appear to expand in width downslope and the length-to-width ratio for most is 1 or less. Finally, the width 
of individual rotated blocks for all of the slumps is the same, 1 to $5 \mathrm{~km}$ (figs. $3,7 \mathrm{~b}-7 \mathrm{f}$ ).

In keeping with the classification defined by Varnes (1978) this group of mass wasting features are best termed progressive slumps. Vames (1978) suggests that the term progressive should be applied when the direction of extension is unknown or in both upslope and downslope directions. Because of the paucity of seismic-reflection data perpendicular to the slumps the exact mode of failure is not yet known, thus we have termed these progressive slumps. These failures may be shallow successive or stepped, rotational slips involving only the upper few hundred meters of sediment or much deeper multiple rotational rock slides with a common deepseated slip sole. $3.5 \mathrm{kHz}$ records only image the upper $100 \mathrm{~m}$ of sediment and give no information about the basal surface of failure. Likewise, hyperbolic reflections on unprocessed airgun records do not yet yield any information about how deep the faults extend into the flanks of the seamounts. Further processing and migration may resolve this issue. However, the arcuate nature of the failure appears to limit the ability of these individual blocks to be continuous for long distances (the longest scarp measures just over $25 \mathrm{~km}$ in length). The arcuate shape combined with the concave surface of failure may also limit the strength of the blocks in depth.

The progressive slumps appear to be restricted to the older islands and seamounts along the chain. Unanalyzed data collected on the northern side of the Hawailan Ridge also shows features on GLORIA imagery similar to these (see data collected on F10-91-HW). However, these features are not visible on GLORIA imagery for any of the islands younger than Nihau. The areal extent of these features varies greatly. However, most are bounded or covered by large blocky debris slides suggesting that their extent may be much greater than that observed.

It is unclear if these failures are a late stage development along the chain or are just hidden from GLORIA's view on the younger islands because of poor sediment cover. Geophysical profiles collected off Salmon Bank slump show rotated blocks with little if any sediment cover that are not imaged by GLORIA.

The following sections are more detailed descriptions of each of the $\mathbf{5}$ progressive slumps mapped in the survey area. 


\section{Nero Slump}

Nero slump is located in the far western portion of the surveyed area (fig. $7 \mathrm{~b}$ ), roughly 40 $\mathrm{km}$ south of the summit of Nero Seamount. The failure is bounded on the west by a small seamount, to the southeast by a small lava flow and to the southwest by the large bedform field. The feature is interpreted as a progressive slump based on its similar appearance on GLORIA images to failures mapped farther to the east (ie. Salmon Bank slump). On GLORIA imagery, the slump appears as narrow, sinuous, high-backscatter bands that are most likely reflections from the head scarps separating rotated blocks. The slump contains at least 11 successive fault scarps that can be mapped laterally for up to $16 \mathrm{~km}$ and are separated by blocks that are 1 to 3 $\mathrm{km}$ wide. Line 11 is the only geophysical line to cross the feature and unfortunately crosses it parallel to strike. The $3.5 \mathrm{kHz}$ profile shows hummocky reflections with little or no transparent drape at the base of the slump.

\section{Salmon Bank Slump}

Salmon Bank slump is located on the lower flank of Salmon Bank about $\mathbf{4 0} \mathrm{km}$ south of the summit (fig. 7c). GLORIA imagery, shows the failure is composed of sinuous, narrow, highbackscatter bands, 1 to $4 \mathrm{~km}$ apart that arc around the base of the seamount for $50 \mathrm{~km}$ and rise up the eastern flank a distance of $35 \mathrm{~km}$. The area imaged by GLORIA covers $1750 \mathrm{~km}^{2}$ however, $3.5 \mathrm{kHz}$ profiles collected along line 7 show that the failure extends $100 \mathrm{~km}$ along the length of the southern flank. The uppermost slope of the seamount is covered with sediment and shows extensive channeling. A debris slide containing blocks up to $3 \mathrm{~km}$ wide litter the southeastern portion of the slump.

The high-backscattered bands can be identified on $3.5 \mathrm{kHz}$ profiles as the head scarps of the rotated blocks (fig. 3) with displacements ranging from 10 to $40 \mathrm{~m}$. 11 successive scarps are visible and one is continuously mappable for over $25 \mathrm{~km}$. Sediment cover measured along the clearly imaged scarps on the eastern portion of line 7 show a uniform $25 \mathrm{~ms}$ of transparent drape. The western segment of the line that is not imaged by GLORIA shows little if any sedi- 
ment cover.

\section{Lisianski Slump}

At the base of Lisianski Island is located Lisianski slump, roughly $70 \mathrm{~km}$ southeast of the summit (fig. 7d, the slump is imaged due south of Pioneer Bank). Sonar images of the progressive failure show the characteristic narrow, sinuous, high-backscatter bands seen on similar features mapped in the surveyed region. Six scarps are imaged separated by blocks ranging from 1 to $5 \mathrm{~km}$ in width. The longest continuous scarp mapped is $13 \mathrm{~km}$ long. The $3.5 \mathrm{kHz}$ profiles collected along line 5 show that vertical displacements are as great as $100 \mathrm{~m}$ and sediment cover is up to $40 \mathrm{~ms}$ thick. Profiles also show the failures continue to the base of the slope. However, sediment cover is thin or absent near the base of the slope where the fault scarps are poorly imaged.

GLORIA imagery shows that Lisianski slump is about $20 \mathrm{~km}$ long down slope and $30 \mathrm{~km}$ wide covering an area of $600 \mathrm{~km}^{2}$. However, a massive debris avalanche covers most of the region west of the slump and likewise, farther up the slope possibly masking its total extent. East of the failure lies the major rift that extends south of Pioneer Bank. South of the failure a small seamount and it's associated lava flow are imaged (fig. $7 \mathrm{~d}$, lower left).

\section{Northhampton Slump}

Located at the base of east Northhampton Seamount, $40 \mathrm{~km}$ from the summit is Northhampton slump (fig. 7e). The area of the failure, visible on GLORIA imagery is about 1400 $\mathrm{km}^{2}$. The slump, extends $40 \mathrm{~km}$ down slope and is $30 \mathrm{~km}$ wide. East of this progressive slump resides a partially buried lava flow that is littered with small debris slide blocks. The slope above the slump, is also covered by debris slide deposits and is incised by several channels and gullies (fig. 7e). West of the failure is another large lava flow that occupies a broad depression in the seafloor. 
Gloria imagery shows 14 subparallel head scarps as sinuous, narrow, high-backscatter bands separated by 1 to $3 \mathrm{~km}$ wide blocks. The longest continuous scarp is $20 \mathrm{~km}$ long. The $3.5 \mathrm{kHz}$ profiles collected near the base of the slope along line 5 show hyperbolic reflections with $10 \mathrm{~ms}$ of transparent drape, having fault offsets of up to $60 \mathrm{~m}$. Farther up the slope along line $16,3.5 \mathrm{kHz}$ profiles show stratified hyperbolic reflections $70 \mathrm{~ms}$ thick and scarps reaching $90 \mathrm{~m}$ high.

\section{Necker Slump}

Necker slump is located southwest of Necker Island about $40 \mathrm{~km}$ from the summit, extending $15 \mathrm{~km}$ down slope and $25 \mathrm{~km}$ across the flank of the island (fig. 7f). On the west the failure is bounded by Necker Ridge, and to the east lies a debris slide with blocks reaching $2 \mathrm{~km}$ across. Seven successive fault scarps are visible on GLORIA imagery and appear as sinuous, narrow, high-backscatter bands. Each scarp is separated by blocks 1 to $4 \mathrm{~km}$ wide, and the longest scarp measures $15 \mathrm{~km}$. Line 15 crosses the failure parallel to strike and shows only chaotic hyperbolic reflections. Line 2 crosses the slump obliquely showing hyperbolic reflections with up to $40 \mathrm{~ms}$ of transparent drape and fault displacements of $20 \mathrm{~m}$.

\section{CONCLUSIONS}

The data presented in this preliminary report displays a wide and complex potpourri of features that show: 1) the Cretaceous seafloor before the Hawaiian Ridge formed; 2) the formation of the Hawaiian Ridge; 3) how the Hawaiian Ridge has matured through time; and 4) the effect of active bottom currents on the sediment shed from the Hawaiian Ridge. Final answers to many questions posed in this report await image and seismic processing, and subsequent sampling.

\section{ACKNOWLEDGEMENTS}

We thank the captain and crew of the MN Farnella, and the scientific and technical staffs of the USGS and IOS, whose help and professionalism contributed to the success of the survey. 
We also thank Michael Torresan for his review of the manuscript, and Phyllis Swenson who drafted Figure 1.

\section{REFERENCES CITED}

Atwater, T., and Severinghaus, J., 1989, Tectonic maps of the northeast Pacific, in Winterer, E.L., Hussong, D.M., and Decker, R. W., eds., The Eastern Pacific Ocean and Hawaii: Boulder, Colorado, Geological Society of America, The Geology of North America, v. N.

Chase, T.E., Menard, H.W., and Mammerick, J., 1972, Bathymetry of the North Pacific, Scripps Institute of Oceanography and Institute of Marine Resources, chart no. 8.

Clague, D.A., and Dalrymple, G.B., 1987, The Hawaiian-Emperor volcanic chain, Part 1: U.S. Geological Survey Professional Paper, 1350, Chapter 1, p. 5-54.

Clague, D.A., Moore, J.G., Torresan, M.E., Holcomb, R.T., and Lipman, P.W., 1988, Shipboard report for Hawaii Gloria ground-truth cruise F2-88-HW, 25 February - 9 March, 1988: U.S. Geological Survey Open-File Report 88-292, 54 p.

Clague, D.A., Holcomb, R.T., Torresan, M.E., and Ross, S.L., 1989, Shipboard report for Hawaii GLORIA ground-truth cruise F11-88-HW, 25 October - 7 November, 1988: U.S. Geological Survey Open-File Report 89-109, 33 p.

Clague, D.A., Holcomb, R.T., Sinton, J.M., Detrick, R.S., and Torresan, M.E., 1990, Pliocene and Pleistocene alkalic flood basalts on the seafloor north of the Hawaiian islands: Earth and Planetary Science Letters, v. 98, p. 175-191.

Holmes, M.L., Moore, J.G., Holcomb, R.T., and Belderson, R.H., 1987, Preliminary cruise report, Research Vessel FARNELLA. Windward Hawaii, F5-86-HW: U.S. Geological Survey Administrative Report.

Gann, J.T., 1988, Integrated GPS, range-range and hyperbolic Loran C marine navigation system for use on IBM AT or compatible micro computer: U.G. Geological Survey Open-File Report 88-562, 39p.

Greene, H.G., Dalrymple, G.B., and Clague, D.A., 1978, Evidence for northward movement of the Emperor Seamounts: Geology, v. 6, p. 70-74.

Kayen, R.E., Hampton, M.A., Wilson, J.B., and Bishop, D.G., 1990, GLORIA survey of part of the Hawaiian Exclusive Economic Zone, F1-90-HW: U.S. Geological Survey OpenFile Report 90-345, $53 \mathrm{p}$.

Laughton, A.S., 1981, The first decade of GLORIA: Journal of Geophysical Research, v. 86, p. 11511-11534.

McGregor, B.A., Kappel, E.S., Wilson, J.B., Trincardi, F., Whittington, R.J., Mayer, W., and Campbell, J., 1991, Cruise report Hawwailan GLORIA leg 7, F10-88-HW: U.S. Geological Survey Open-File Report 91-333, 52p.

Moore, J.G., and Clague, D.A., 1987, Coastal lava flows from Mauna Loa and Hualalai volcanoes, Kona, Hawaii: Bulletin of Volcanology, v. 49, p. 752-764. 
Moore, J.G., and Clague, D.A., 1988, Offshore geology of Mahukona, Kohala, Mauna Kea, Hualali and Mauna Loa volcanoes to the northwest of Hawaii: EOS, v. 69, n. 44, p. 1445.

Moore, J.G., Clague, D.A., Holcomb, R.T., Lipman, P.W., Normark, W.R., and Torresan, M.E., 1989, Prodigious submarine landslides on the Hawailan Ridge: Journal of Geophysical Research, v. 94, no. B12, p. 17465-17484.

Moore, J.G., Clague, D.A., Ludwig, K.R., and Mark, R.K., 1990, Subsidence and volcanism of the Haleakala Ridge, Hawaii: Journal of Volcanology and Geothermal Research, v. 42, p. 273-284.

Normark, W.R., Lipman, P.W., Wilson, J.B., Jacobs, C.L., Johnson, D.P., and Gutmacher, C.E., 1987 Preliminary Cruise Report, Hawaiian GLORIA Leg 2, F6-86-HW, November 1986, U.S. Geological Survey Open-File Report 87-298, 42p.

Normark, W.R., Holcomb, R.T., Searle, R.C., Somers, M.L., and Gutmacher, C.E., 1989 Cruise Report, Hawaiian GLORIA Legs 3 and 4, F3-88-HW and F4-88-HW, U.S. Geological Survey Open-File Report 89-213, 56p.

Pickthom, L.G., Drake, D.E., and Jacobs, C.L., 1991, Cruise report, Hawwaiian GLORIA cruise F13-89-HW: U.S. Geological Survey Open-File Report 91-337, 48p.

Saito, K., and Ozima, M., 1977, ${ }^{40} \mathrm{Ar}-{ }^{39} \mathrm{Ar}$ Geochronologicla studies on submarine rocks from the westem Pacific area: Earth and Planetary Science Letters, v. 33, p. 353-369.

Somers, M.L., Carson, R.M., Revie, J.A., Edge, R.H., Barrow, B.J., and Andrews, A.G., 1978, GLORIA II - an improved long range side-scan sonar: Oceanology International 78, Technical session J, London: BPS Exhibitions Ltd., p. 16-24.

Torresan, M.E., Shor, A.N., Wilson, J.B., and Campbell, J., 1989, Cruise report, Hawaiian GLORIA leg 5, F5-88-HW: U.S. Geological Survey Open-File Report 89-198, 55 p.

Torresan, M.E., Clague, D.A., and Jacobs, C.L., 1991, Cruise report, Hawaiian GLORIA cruise F12-89-HW: U.S. Geological Survey Open-File Report 91-127, 67 p.

Varnes, D.J., 1978, Slope movement types and processes, in Schuster, R.L. and Krizek, R.J., eds., Landslides, Analysis and Control: Washington, D.C., National Academy of Sciences, Spec. Rep. 176, p. 11-33.

Wallin, B.H., 1982, The northern Hawaiian Deep and Arch: Interpretation of geologic history from reflection profiling and echo character mapping: University of Hawaii, MS Thesis, Honolulu, Hawaii, 133 p. 


\section{APPENDIX 1 \\ EQUIPMENT SETTINGS AND COMMENTS}

\begin{tabular}{ll} 
& \multicolumn{1}{c}{$3.5 \mathrm{kHz}$ SYSTEM } \\
& \\
LSR Recorder & Mode - Continuous \\
& PAPER - $100 \mathrm{Ipi}$ \\
& SWEEP $-1 \mathrm{sec}$ \\
& PROGRAM - As required \\
& GAIN - Mid \\
& CONTRAST - Mid \\
& THRESHOLD - Min \\
& GAIN - 6 \\
& POWER - $6 \mathrm{db}$ \\
PTR Transceiver & PULSE WIDTH - Not used \\
& OUTPUT LEVEL - 4-5 \\
& ATTENUATOR - 11.5
\end{tabular}

Fish Depth Compensation $10 \mathrm{~m}$.

$10 \mathrm{kHz}$ SYSTEM

MUFAX Recorder

ATTENUATOR --6 to -18

TIME MARKS- $6 \mathrm{~min}$.

PULSE LENGTH- 2.8 to 5

FISH DEPTH- $2 \times 5 \mathrm{~m}$

GATING SELECTOR- 6

FATHOMS/METERS- Meters

TRIGGER (Left/Center)-as required for scale changes

TVG- Use to suppress outgoing pulse

GATING- Use to "see" bottom through outgoing pulse.

\section{MAGNETOMETER}

Soltec Recorder

CHART SPEED - $40 \mathrm{~cm} / \mathrm{hr}$

Full scale at 100 gamma range

GRAVIMETER

Soltec Recorder

CHART SPEED - $10 \mathrm{~cm} / \mathrm{hr}$ 
APPENDIX I (Continued)

\section{SEISMIC REFLECTION SYSTEM}

LSR Recorder

DISPLAY - Normal

STYLUS SCAN- 2 sec

PAPER- 120 Ipi

MEMORY SWEEP- $6 \mathrm{sec}$

FILTER- out

POLARITY- $/+$

GAIN- 10 to $20^{\prime} \mathrm{clock}$

CONTRAST- -30 to -40

THRESHOLD - 2

Krohn - Hite Filter

MASSCOMP

DMD Delay Box
$20-120 \mathrm{~Hz}$

GAIN SETTING: Pre-amp 0 Post-amp 6 to 18

As required for DWD 


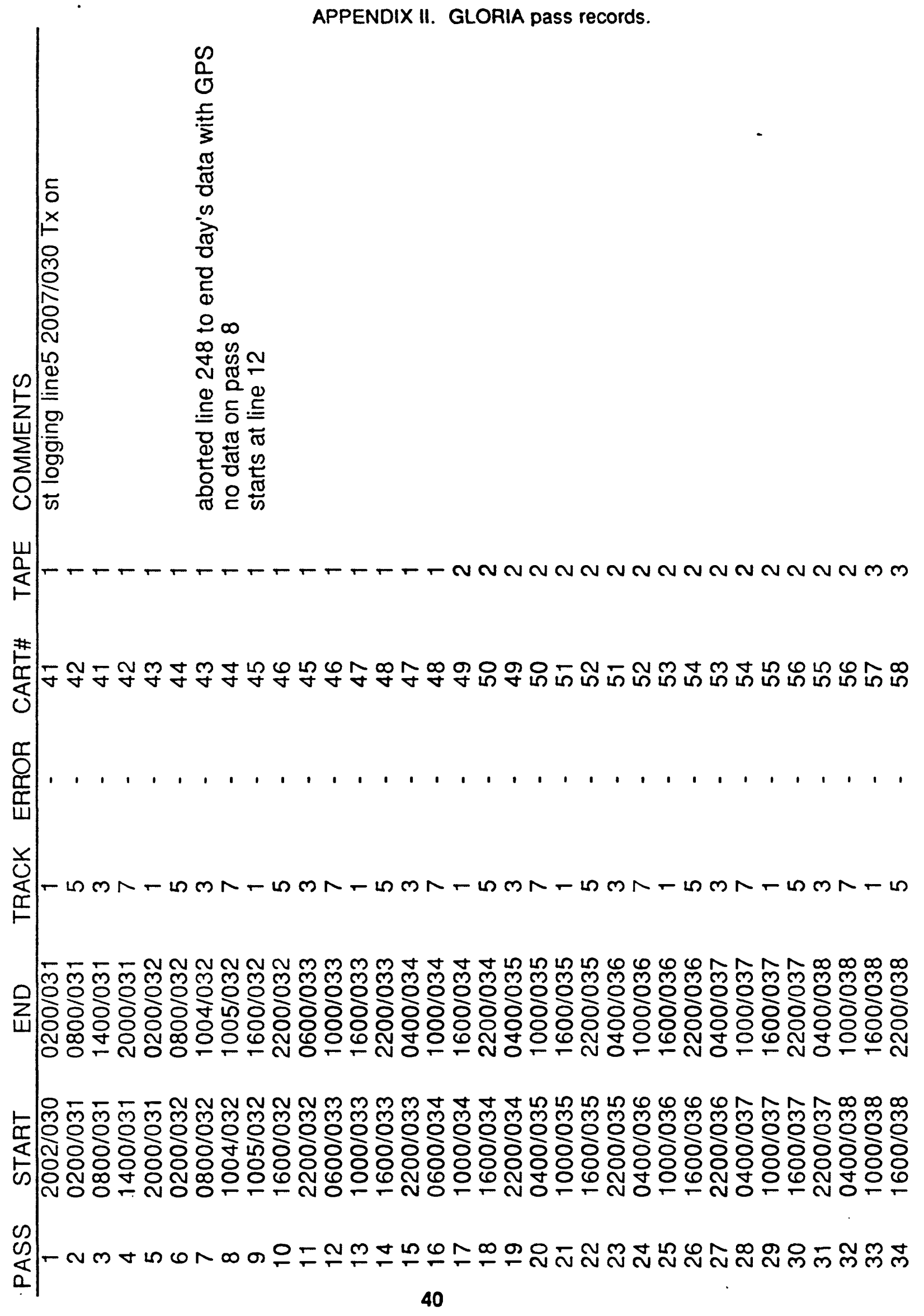


APPENDIX II. (Continued)

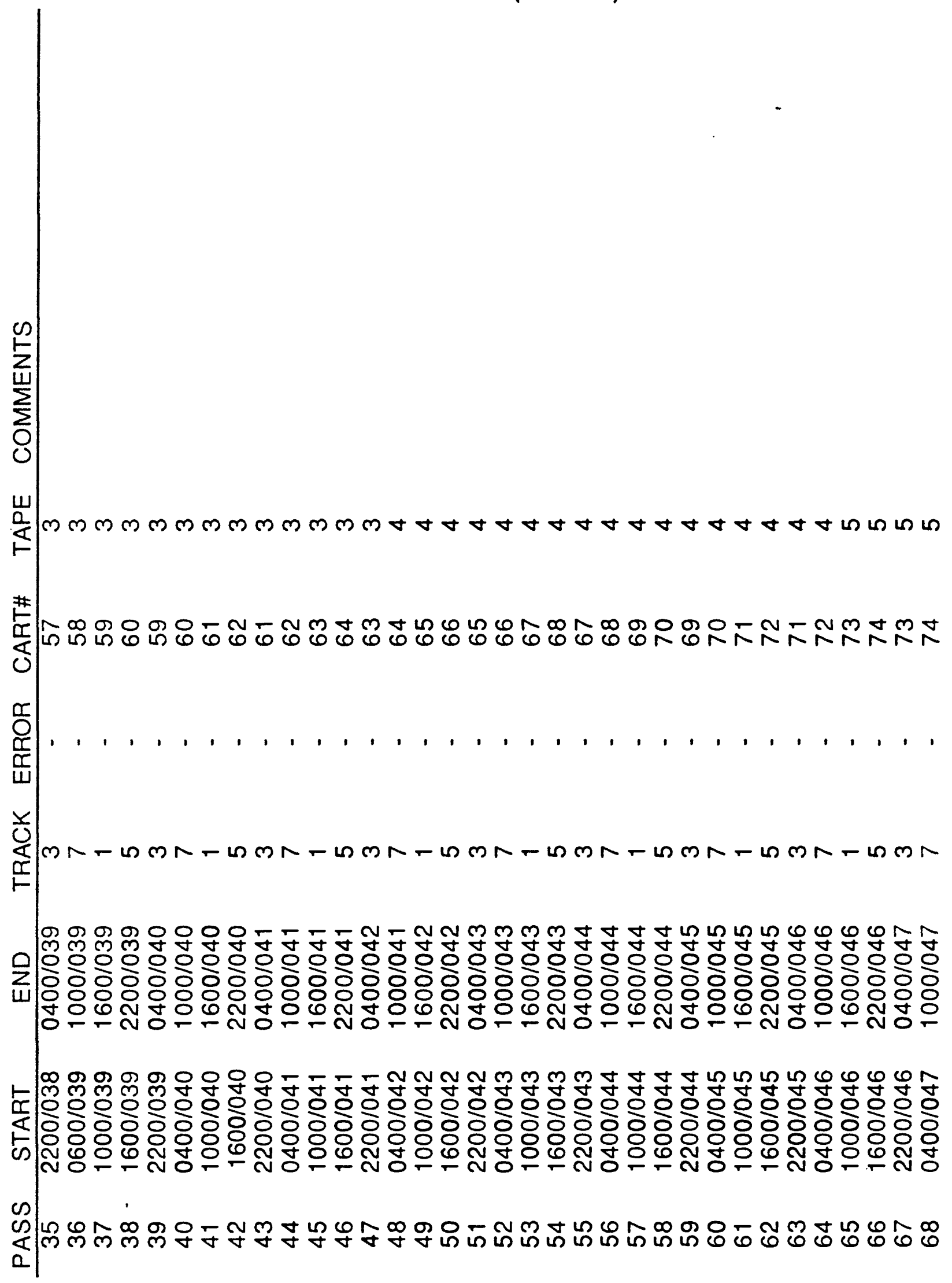









\section{FIGURE CAPTIONS}

Figure 1. A) Bathymetry map of the western portion of the surveyed area showing trackline coverage. Modified from Chase et al. (1972). B) Trackline map of the western portion of the surveyed area. Heavy black lines show locations of figures. C) Bathymetry map of the eastern portion of the surveyed area showing trackline coverage. Modified from Chase et al. (1972). D) Trackline map of the eastern portion of the surveyed area. Heavy black lines show locations of figures.

Figure 2. $3.5 \mathrm{kHz}$ profile along a portion of line 11 (see fig. 1 for location) showing typical horst and graben structure capped by $15-20 \mathrm{~ms}$ of transparent drape.

Figure 3. $3.5 \mathrm{kHz}$ profile along a portion of line 7 showing hyperbolic reflections from fault scarps caused by rotated slump blocks near the base of Salmon Bank slump (see fig. 1 for location). Note the transparent cover of about 20 ms.

Figure 4. $3.5 \mathrm{kHz}$ profile along a portion of line 16 showing characteristic prolonged reflection type (see fig. 1 for location).

Figure 5 . $3.5 \mathrm{kHz}$ profile along a portion of line 5 showing numerous sharp, high frequency, parallel reflections characteristic of the stratified reflection unit (see fig. 1 for location).

Figure 6. $3.5 \mathrm{kHz}$ profile along a portion of line 41 showing the extremely prolonged, very diffuse character of the opaque reflection type (see fig. 1 for location).

Figure 7. Unprocessed GLORIA mosaic and interpretive line drawings for F2-90HW. See explanation and text for details.

Figure 8. $3.5 \mathrm{kHz}$ profile of a portion of line 9 showing the migration of bedforms upslope (see fig. 1 for location). Note deposition of transparent layer on upslope (lee) side. 
Figure 9. $3.5 \mathrm{kHz}$ profile of a portion of line 11 showing crossbedding covered by 10 ms of the transparent layer. 
Figure 1.

Figure 1. (Continued)

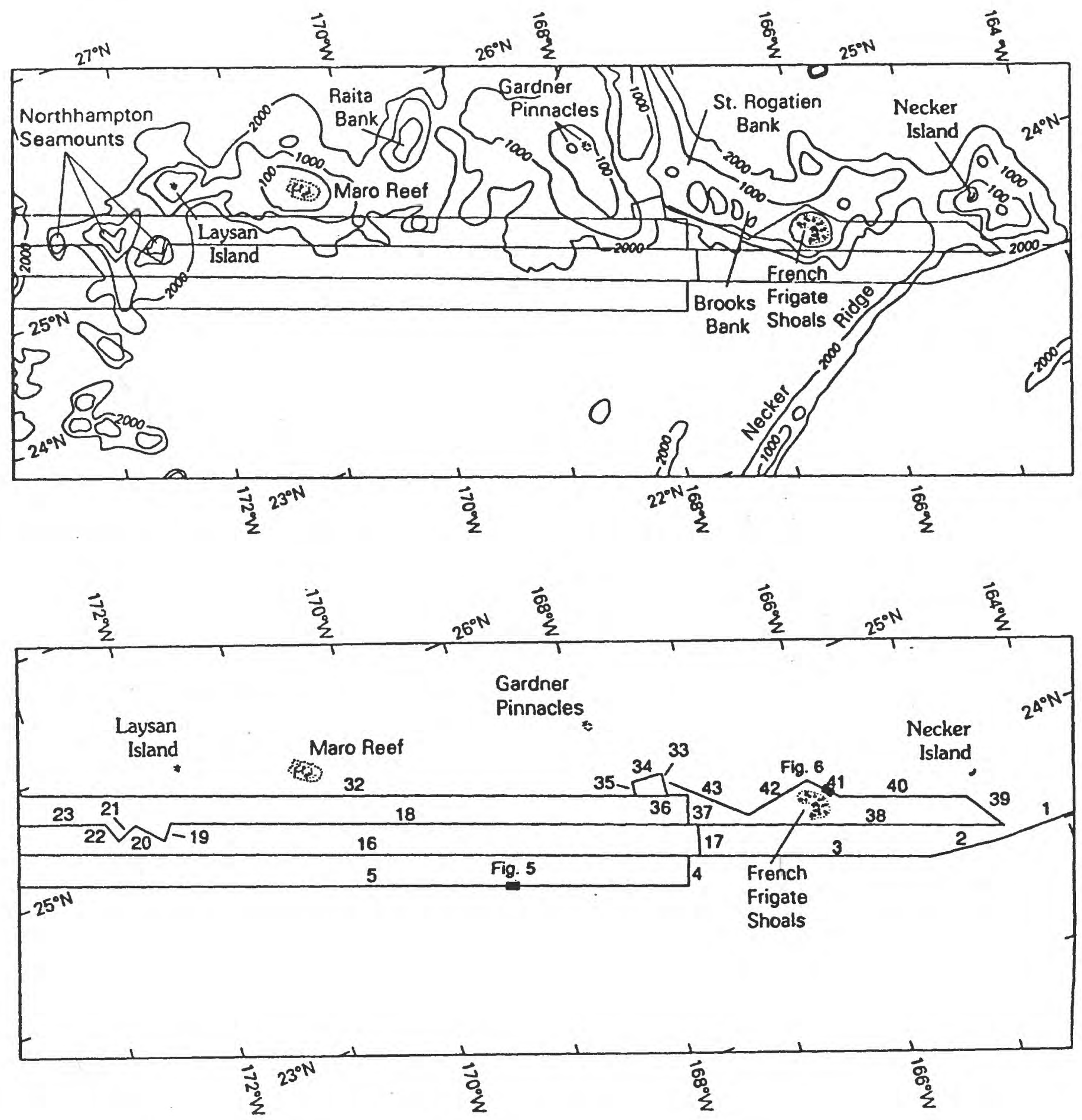


Figure 2.

WATER DEPTH (METERS)




Figure 3.

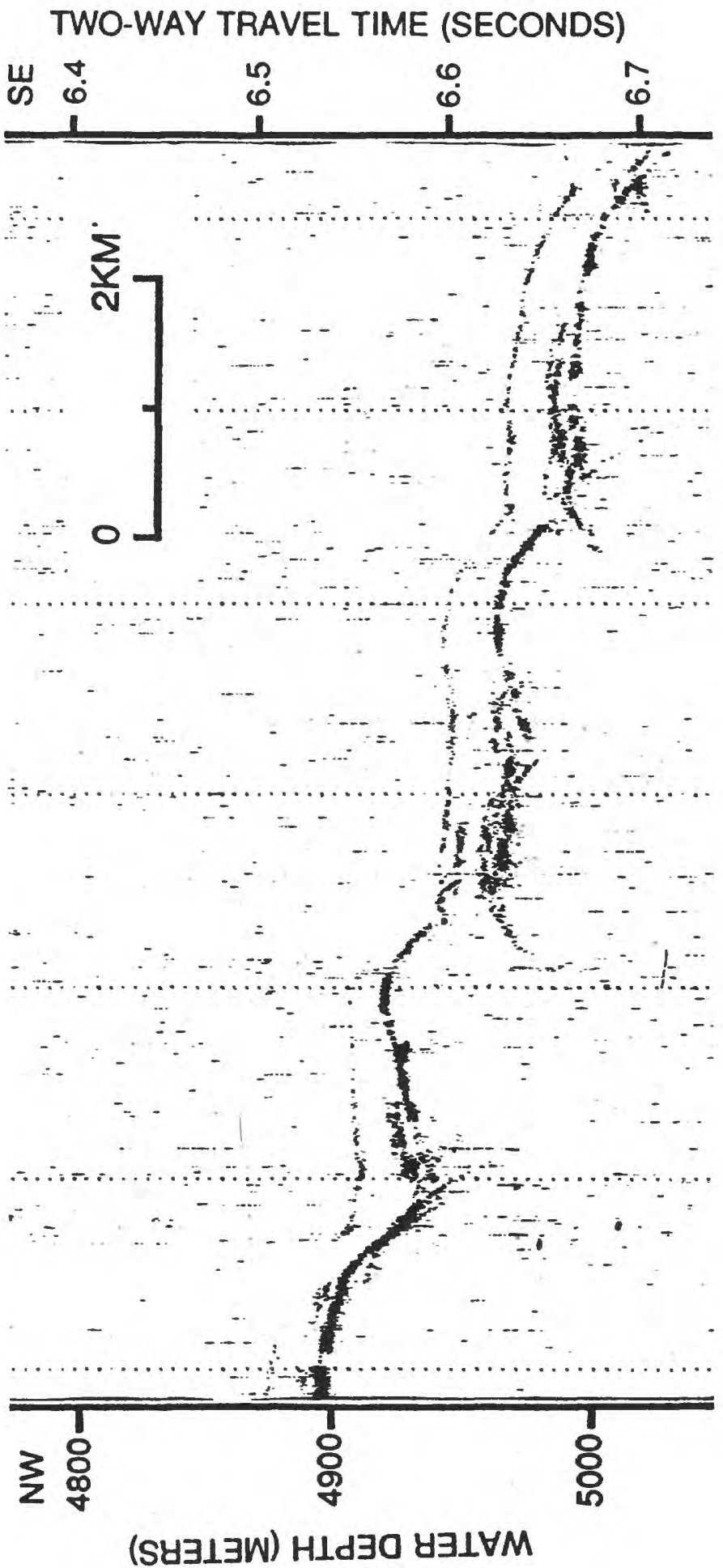


Figure 4.

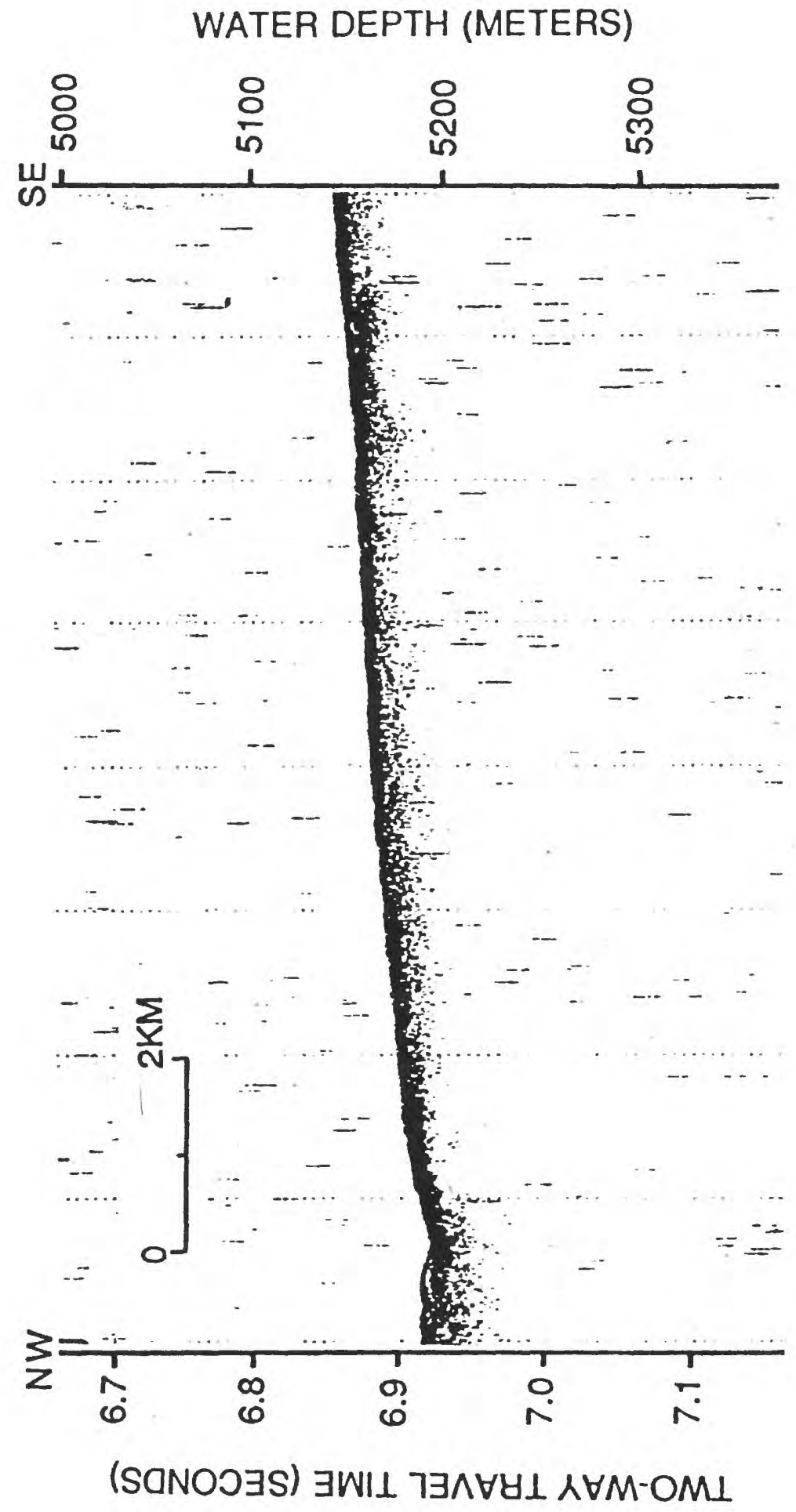


Figure 5.




Figure 6.

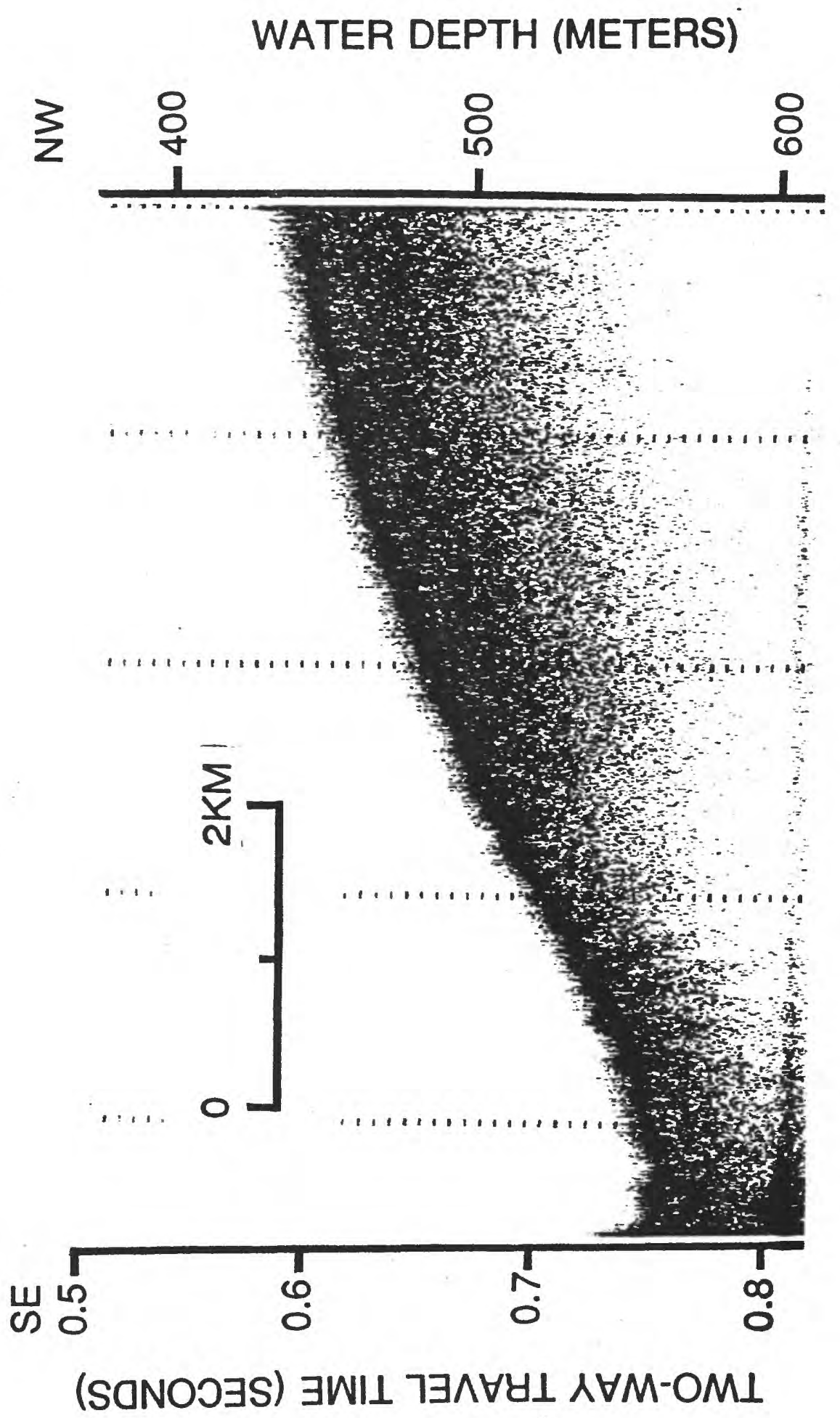


Figure 7.

\section{EXPLANATION}

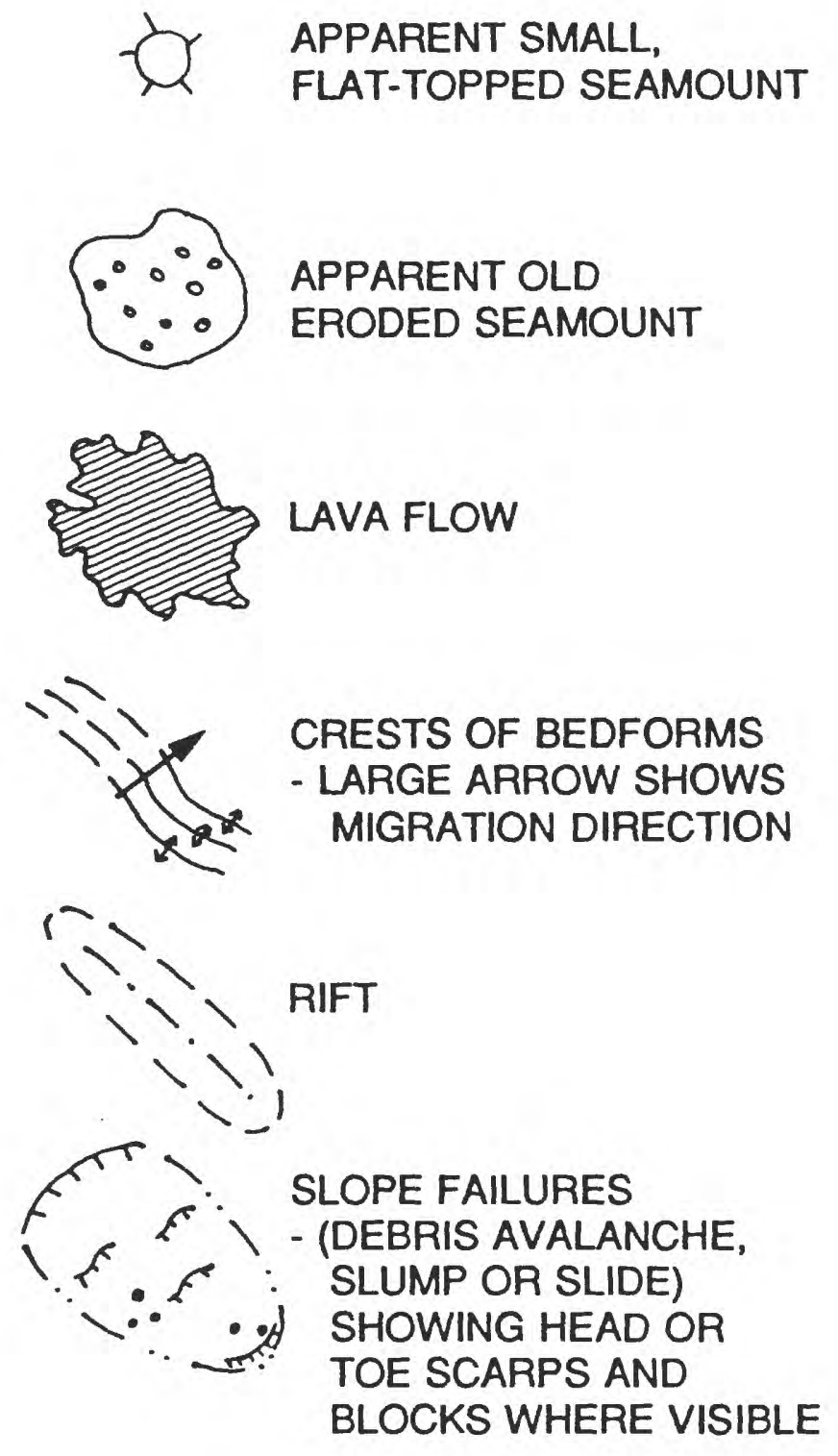

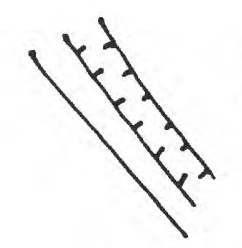

FAULT SCARP

- HACHURES ON THE DOWNTHROWN SIDE WHERE KNOWN


RIDGE 
Figure 7a
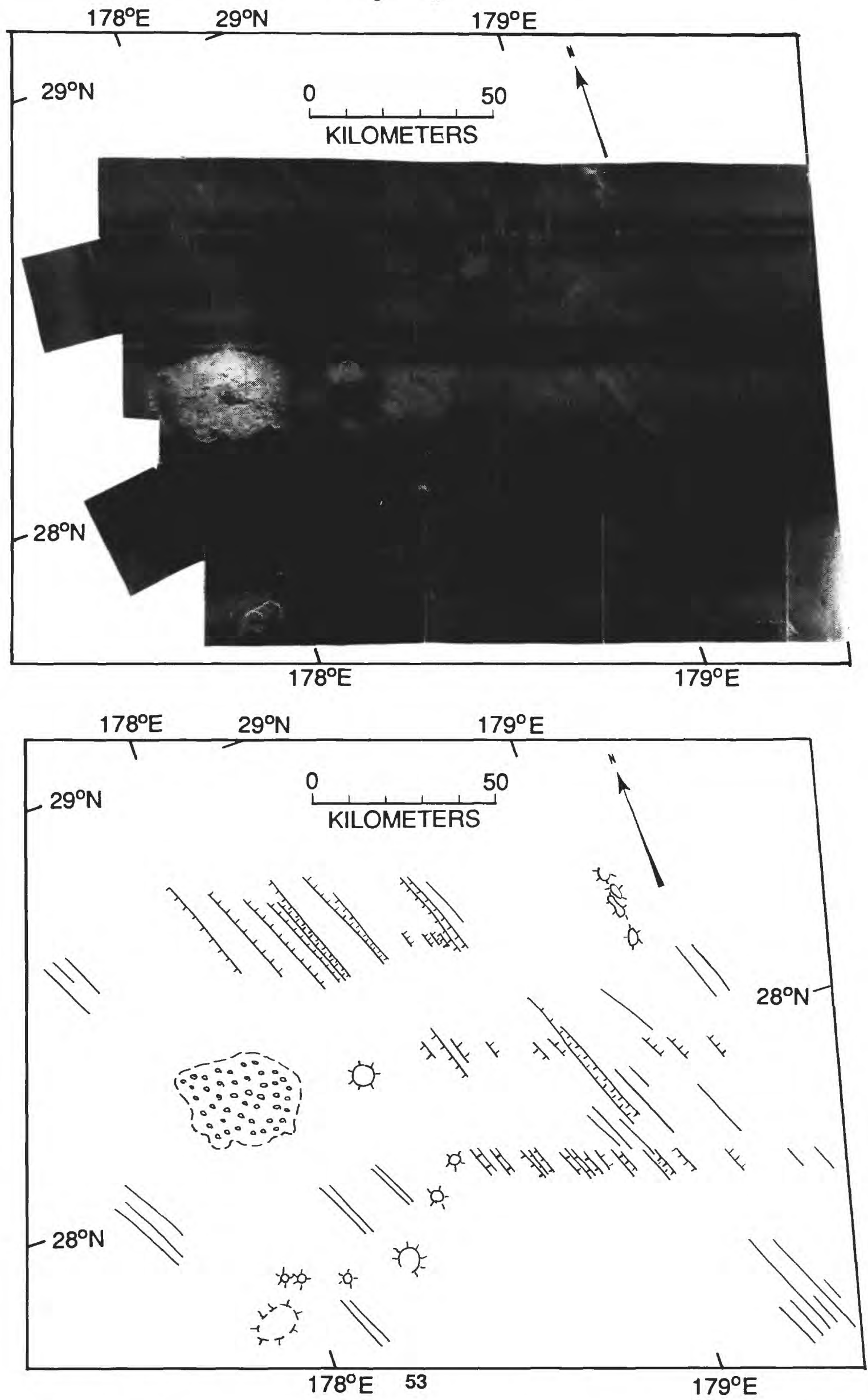






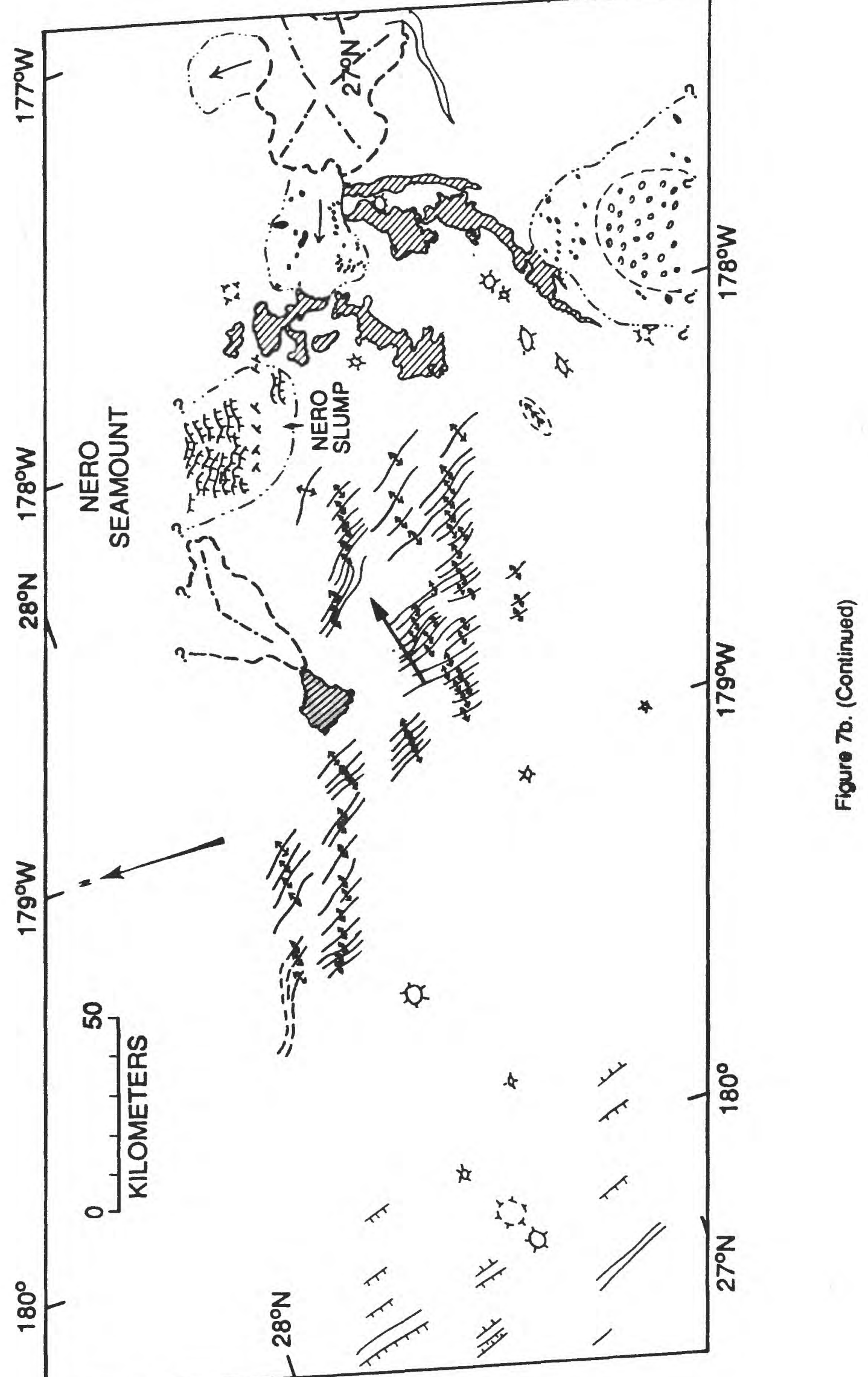


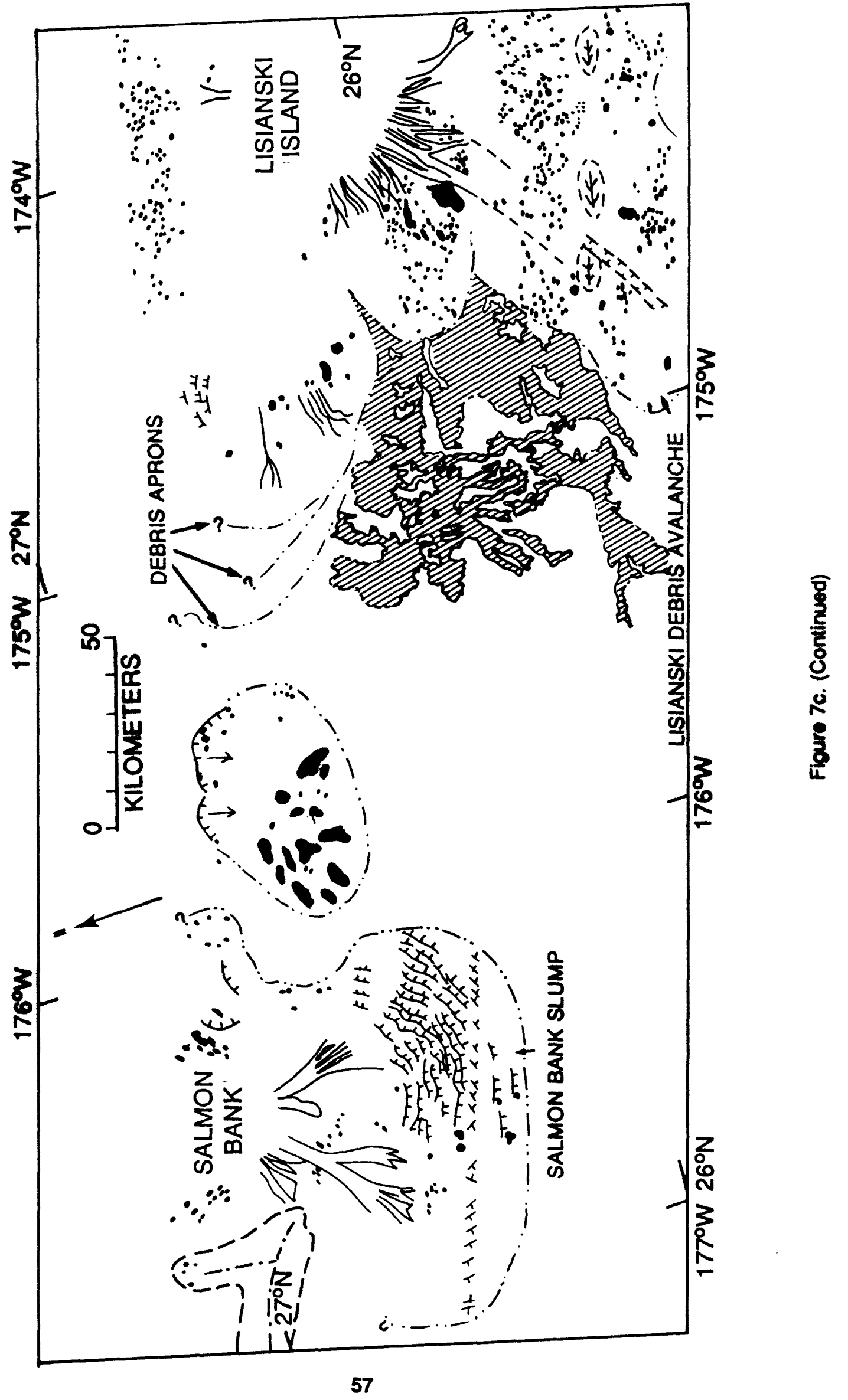











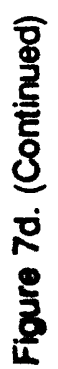




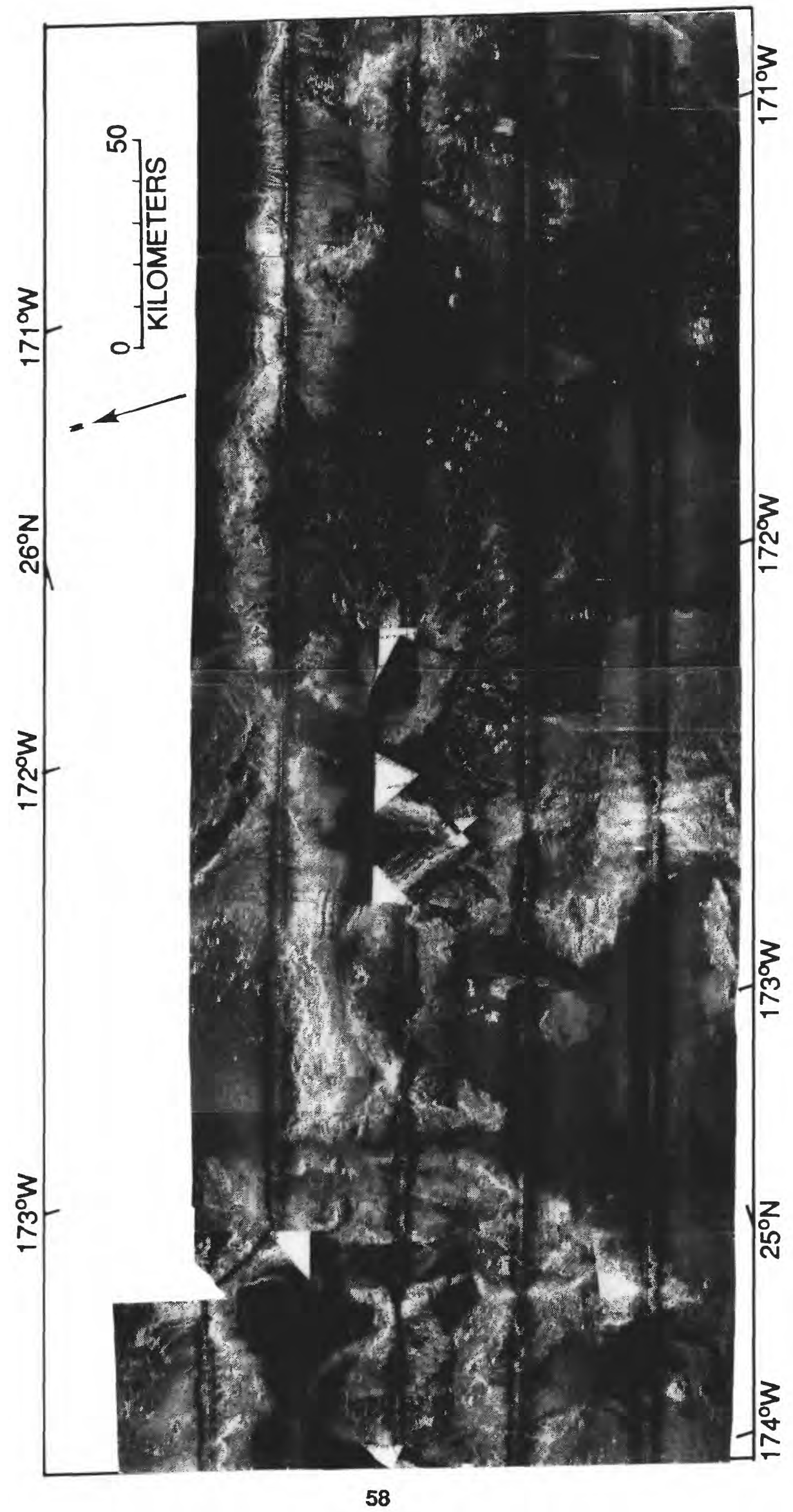

중
민
온 




ำ 




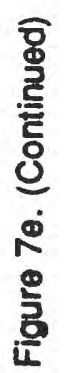




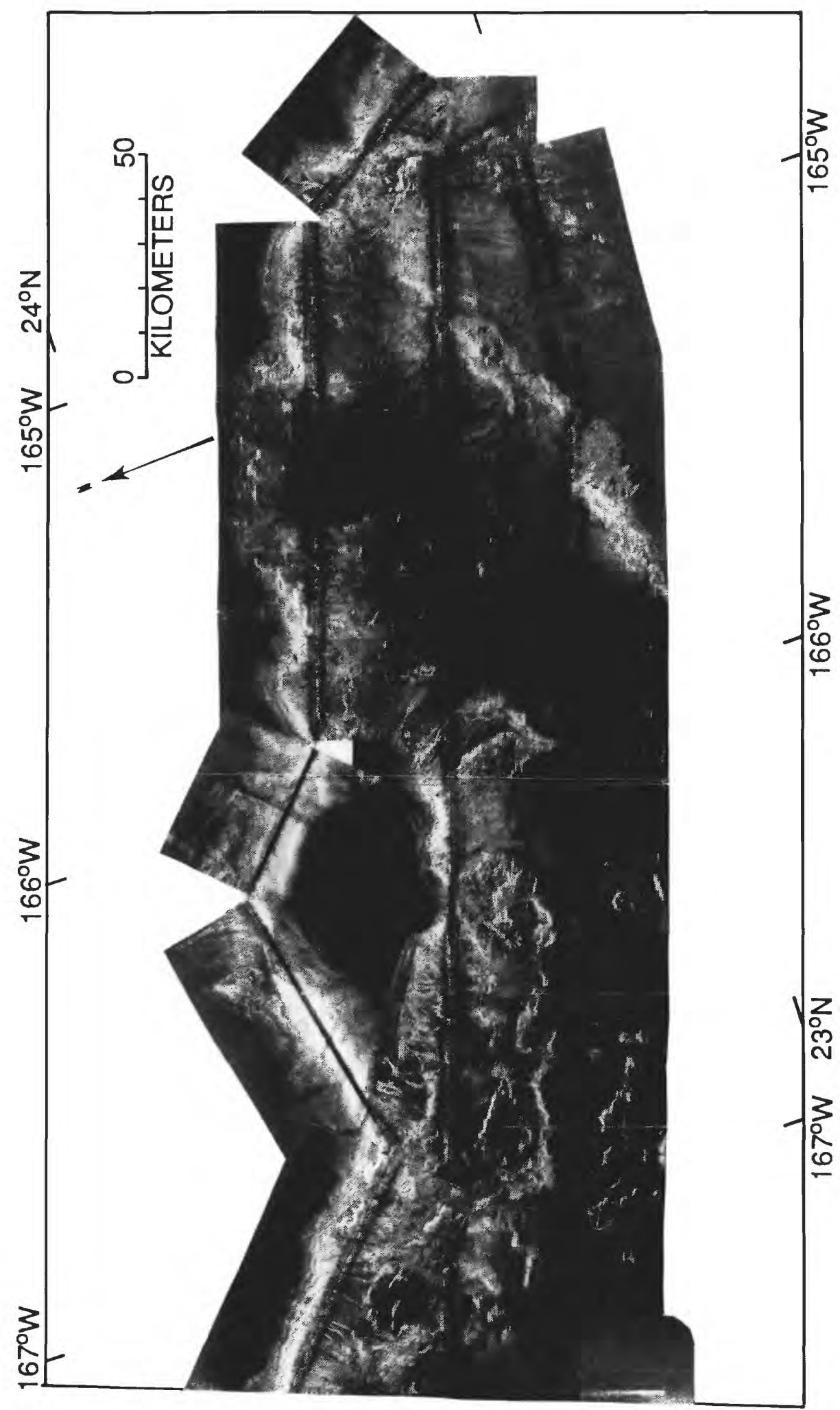




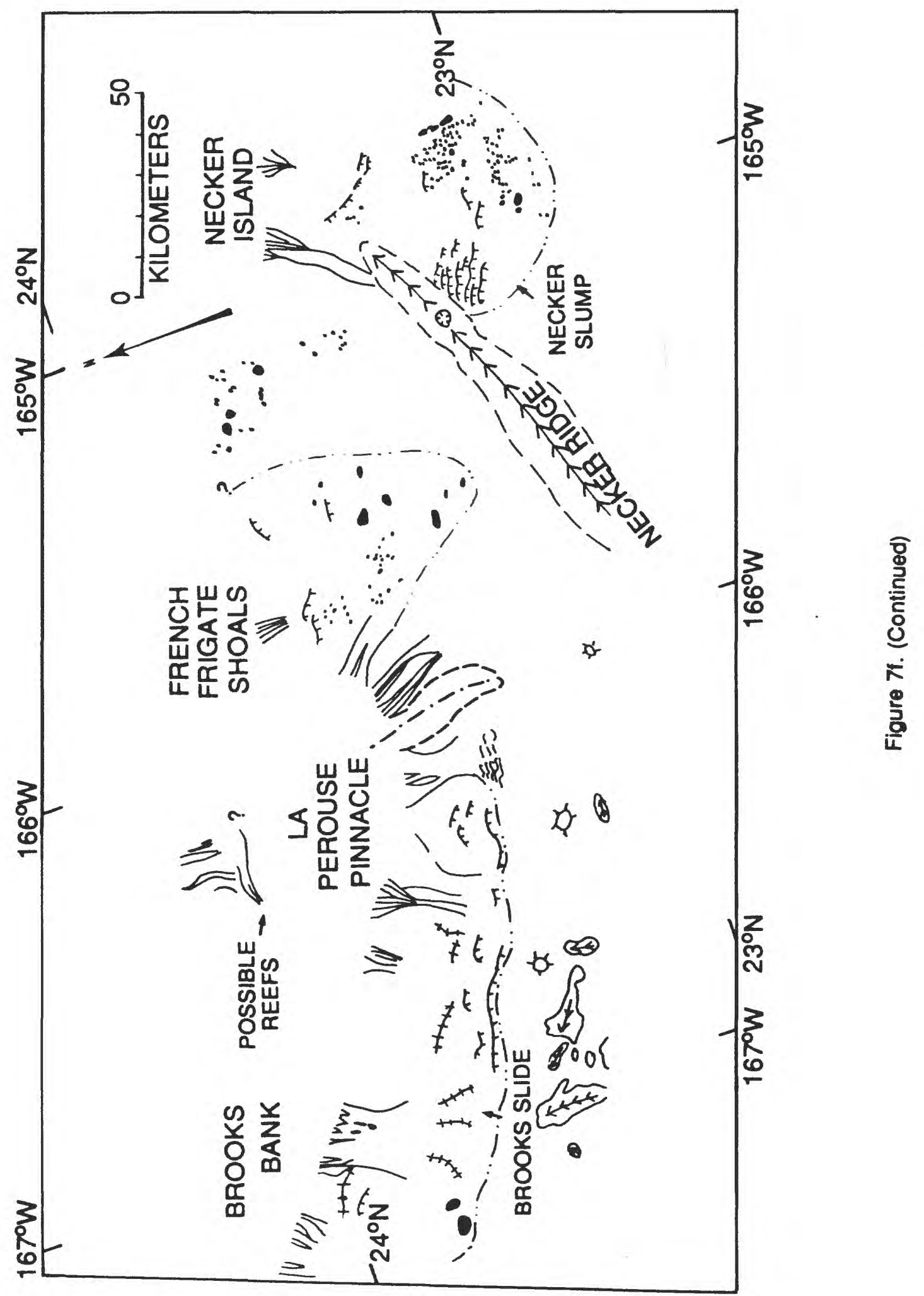


Figure 8.

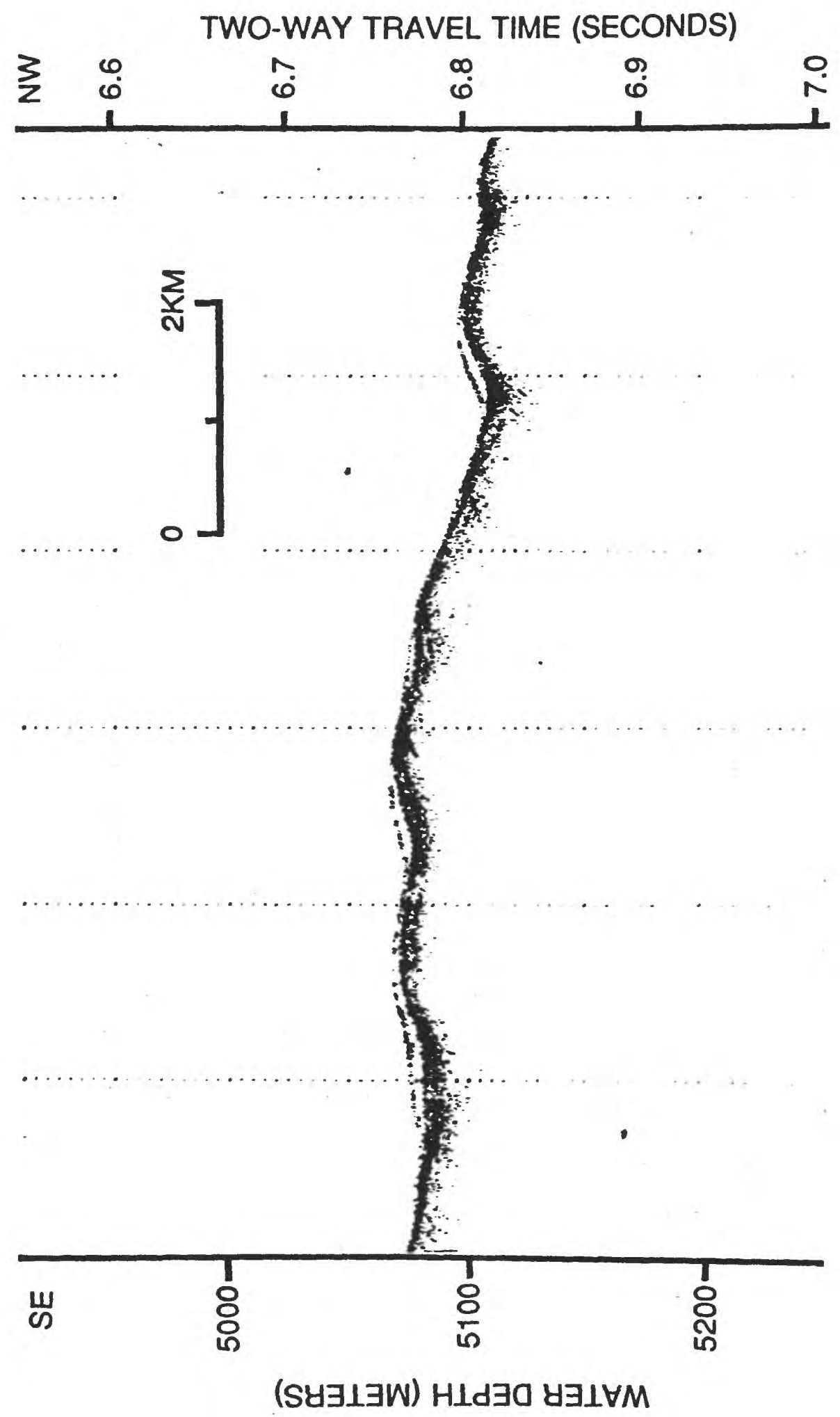


Figure 9.



